
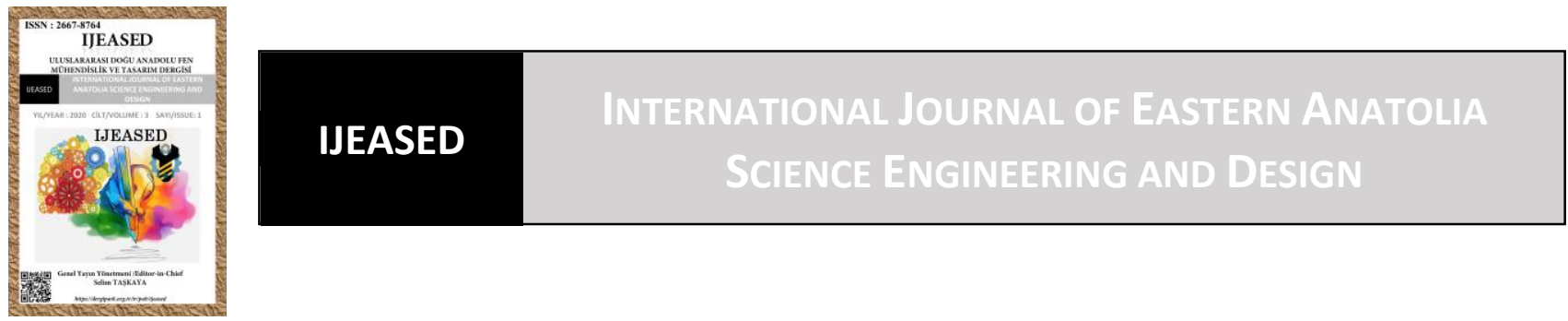

\author{
Uluslararası Doğu Anadolu Fen Mühendislik ve Tasarım Dergisi \\ ISSN: 2667-8764 , 3(1), 298-332, 2021 \\ https://dergipark.org.tr/tr/pub/ijeased
}

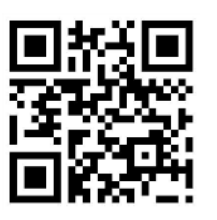

Derleme Makalesi / Review Article

Doi: $\underline{10.47898 / \text { ijeased.880596 }}$

\title{
Türkiye’de Adaçayı Yetiştiriciliği ve Ticari Önemi
}

\author{
Sinem ELMAS *
}

Muğla Sıtkı Koçman Üniversitesi, Fen Fakültesi, Biyoloji Bölümü, 48000, Türkiye.

\begin{tabular}{l|lc|c}
\hline \multicolumn{1}{c|}{ Yazar Kimliği / Author ID (ORCID Number) } & \multicolumn{3}{|c}{ Makale Süreci / Article Process } \\
\hline $\begin{array}{l}\text { *Sorumlu Yazar / Corresponding author: Sinem Elmas } \\
\text { sinemelmas @ hotmail.com.tr }\end{array}$ & \multicolumn{1}{|c}{ Geliş Tarihi / Received Date $:$} & 15.02 .2021 \\
\hline Revizyon Tarihi / Revision Date : & 07.04 .2021 \\
iD https://orcid.org/0000-0002-2872-9990, S. Elmas & Kabul Tarihi / Accepted Date : & 10.04 .2021 \\
\hline
\end{tabular}

Alıntı / Cite : Elmas, S. (2021). Türkiye’de Adaçayı Yetiştiriciliği ve Ticari Önemi, Uluslararası Doğu Anadolu Fen Mühendislik ve Tasarım Dergisi, 3(1), 298-332.

\section{Özet}

Günümüzde tıbbi ve aromatik bitkiler farklı alanlarda ve endüstride yoğun olarak tüketilmektedir. Tüketime paralel olarak, bu bitkilerin dünyadaki ticaret hacmi her geçen gün artmaktadır. Ülkemizin önemli dış satım ürünlerinden biri adaçayı ve adaçayı yağıdır. 2020 yılında yaklaşık 2.176 ton adaçayı ihracatına karşılık 8.155.503 dolar ve $27.396 \mathrm{~kg}$ adaçayı yağı ihracatına karşılık 173.504 dolar döviz girdisi elde edilmiştir. Adaçayının ticareti doğadan toplama yoluyla ve farklı illerde tarımı yapılarak gerçekleştirilmektedir. Doğadan toplamada istenilen kalite ve standartta ürün eldesi zordur. Ayrıca aşırı ve bilinçsiz toplama adaçayı popülasyonların aşırı sömürülmesine, sürdürülemez şekilde tükenmesine ve genetik tabanlarının daralmasına yol açmaktadır. Bu nedenle sürdürülebilir kullanımının sağlanabilmesi için, dünya piyasalarının ihtiyaç duyduğu miktar ve standartlarda, kaliteli ve yüksek verime sahip adaçayı yetiştiriciliğinin yaygınlaştırılması gereklidir. Önceki çalışmalar, adaçayı üretiminde verim ve kalitenin, yetiştiriciliğin yapıldığı bölgeye, bölgenin iklim ve toprak koşullarına, hasat zamanlarına, kurutma koşullarına ve tarımsal uygulamalara göre farklılık gösterdiğini kanıtlamıştır. Bu derlemede, ülkemizde doğal yayılış gösteren Salvia tomentosa Mill. ve Salvia fruticosa Mill. ile yetiştiriciliği yapılan Salvia officinalis türlerinin genel durumu, yetiştiricilikte yapılan farklı uygulamalar, karşılaşılan sorunlar ve bunların sonuçları ile bu türlerin ticari önemine değinilmiştir.

Anahtar Kelimeler: Adaçayı, Yetiştiricilik, İhracat, İthalat, Türkiye.

\section{Sage Growing and Commercial Importance in Turkey}

\author{
Abstract \\ Today, medicinal and aromatic plants are consumed extensively in different fields and industries. In parallel with \\ consumption, the trade volume of these plants in the world is increasing day by day. One of the important export


products of our country is sage and its essential oil. In 2020, 8,155,503 dollars were obtained with the export of approximately 2,176 tons of sage, and a foreign exchange entry of 173,504 dollars was obtained with the export of $27,396 \mathrm{~kg}$ of sage essential oil. The trade of sage is carried out through cultivation in different provinces and collecting from nature. It is difficult to obtain products with the desired quality and standard in collecting from nature. In addition, excessive and unconscious collecting leads to the over-exploitation of sage populations, their unsustainable extinction, and the narrowing of their genetic base. For this reason, in order to ensure its sustainable use, it is necessary to expand the cultivation of high quality and high yield sage in the amount and standards required by the world markets. Previous studies have showed that the yield and quality of sage production varies according to the region where the cultivation is made, the climatic and soil conditions of the region, harvest times, drying conditions and agricultural practices. In this review, the general situation of Salvia tomentosa Mill. and Salvia fruticosa Mill., which are naturally distributed in our country, and Salvia officinalis species, which are cultivated, and different applications, problems encountered, and their results in cultivation with the commercial importance of these species were mentioned.

Keywords: Sage, Growing, Exports, Imports, Turkey.

\section{Giriş}

Modern tıbbın bilimsel temeli yüzlerce yıl önce terapötik amaçlarla kullanılan tıbbi ve aromatik bitkilere dayanmaktadır. İnsanoğlu günümüzde halen sağlıklı bir yaşam sürdürebilmek, hastalıklardan korunmak ve hastalıklara şifa bulmak için bitkilerin kök, sap, gövde, kabuk, yumru, yaprak, çiçek ve tohum gibi kısımlarından faydalanmaktadır (Bayram ve ark., 2010). Dünya Sağlık Örgütü (DSÖ), 1977'de tıbbi bitkiyi 'bir veya daha fazla organ için tedavi amaçlı kullanılabilen veya faydalı ilaçların sentezi için öncü olan maddeler içeren herhangi bir bitki' olarak tanımlamıştır. Ancak bu tanımlama tedavi edici özellikleri ve bileşenleri bilimsel olarak belirlenmiş bitkiler ile tıbbi amaç için kullanılan ancak henüz kapsamlı bir araştırmaya tabi tutulmamış bitkiler arasında ayrım yapmamaktaydı (Okigbo ve ark., 2009). 20. yüzyıl başlarında biyoteknolojik gelişmeler doğrultusunda yapılan çalışmalarla bitkilerde çok çeşitli biyoaktif bileşenler tanımlanmış, bunların farmasötik önemleri doğrulanmıştır. Böylelikle sentetik ilaçların yarattığı ciddi yan etkiler, medikal ve ekonomik problemler nedeniyle yan etkisi nispeten daha az, doğal ve sağlıklı olarak kabul edilen bitkisel ürünlerle tekrar doğaya dönüş süreci başlamış ve yeni kullanım alanları oluşturulmaya başlanmıştır (Özbek, 2005; Faydaoğlu ve Sürücüoğlu, 2011). DSÖ 2001'de tıbbi bitki için önceki tanımı değiştirerek 'bitki materyallerinin ekstraksiyon, konsantrasyon, fraksiyonasyon, saflaştırma veya diğer fiziksel veya biyolojik süreçlere tabi tutarak üretilen bitkisel preparatlar’ olarak yeniden düzenlemiştir (Okigbo ve ark., 2009).

Tıbbi ve aromatik bitkilerin kullanım alanlarının artmasına paralel olarak dünya ticaret hacmi her geçen gün artmaktadır. Özellikle 2019 yılı sonrası dünya çapında sağlık için tehdit oluşturan pandemik virüs nedeniyle sadece Türkiye'de e-ticaret üzerinden yapılan bitkisel ürünlerin satışlarında \%45 artış görüldüğü bildirilmiştir (Meral, 2020). Ulusal ve uluslararası pazarlarda tıbbi 
ve aromatik bitkilere artan ilgi ve talep, doğal yayılış gösteren bu bitkilerin aşırı sömürülmesine, sürdürülemez şekilde tükenmesine ve genetik tabanlarının daralmasına yol açmaktadır (Rao ve ark., 2004). Bu nedenle söz konusu bitkilerin üretim olanaklarının artırılmasına yönelik çalışmalar çok daha fazla önem arz etmektedir.

Ülkemiz dünya tarımında kültürü yapılan birçok bitkinin gen merkezi konumundadır (Altındal ve Akgün, 2015). Lamiaceae (ballıbabagiller) familyasından olan bazı türlerin yetiştiriciliği ve ticareti yapılmaktadır. Yetiştiriciliği yapılan bir tür de nutrasötik olarak kabul edilen adaçayıdır. Dünya çapında adaçayının drog yaprakları ve uçucu yağı yaygın olarak geleneksel/tamamlayıcı veya alternatif tıpta bitkisel ilaç, gıda, katkı maddesi olarak; parfümeri ve kozmetik alanlarında kullanılmaktadır (Elmas ve Elmas, 2021). Ülkemizde adaçayı ihracatının çok büyük bir kısmını doğadan toplanan Anadolu adaçayı (Salvia fruticosa) ve büyük çiçekli adaçayı (Salvia tomentosa) türleri oluşturmaktadır (Karakuş ve ark., 2017). Doğadan toplamak ekonomik olmasına rağmen istenilen kalite ve standartta ürün elde etmek zordur. Bu nedenle tüketici ve sanayici taleplerini karşılamak üzere dünya piyasalarının ihtiyaç duyduğu nitelikte adaçayı üretimi için ülkemizin farklı illerinde son yıllarda tıbbi adaçayı (Salvia officinalis) yetiştiriciliği yapılmaktadır (Bayraktar ve ark., 2017). Dünyanın pek çok ülkesine, ülkemiz florasında doğal yetişen/yetiştirilen adaçayı ve yağı ihraç edilmekte olup, önemli miktarlarda döviz girdisi sağlanmaktadır. 2019 yılında 2.317 ton adaçayına karşılık 8.680.563 dolar, 2020 yılında 2.176 ton karşılı̆̆ı 8.155.503 dolar; 2019 yılında 18.429 kg adaçayı yağına karşılık 15.555 dolar ve 2020 y1lında ise $27.396 \mathrm{~kg}$ adaçayı yağına karşılık 173.504 dolar döviz girdisi elde edilmiştir (TÜİK, 2021). Dış ticarette üretim ve ticaret miktarları göz önüne alındığında, talep edilen miktar ve kalitede düzenli tedarik sağlayabilmek için adaçayının yetiştiriciliğinin yapılması önem taşımaktadır. $\mathrm{Bu}$ nedenle adaçayı yetiştiriciliğinde bitkinin ihtiyaç duyduğu iklim ve toprak istekleri, en uygun üretim tekniği, ekim ve bakım işlemleri, hasat, kurutma ve ekstraksiyon yöntemleri, hastalık ve zararlılarının bilinmesi yüksek verimli ve kaliteli ürün eldesine katkı sağlar. $\mathrm{Bu}$ derlemede ülkemizin farklı illerinde yapılan çalışmalar referans alınarak adaçayı yetiştiriciliği ve yıllara göre ticari önemi ele alınmıştır.

\section{Adaçayı (Salvia L.) hakkında genel bilgiler}

Latince "salvare" yani iyileşmek, kurtulmak anlamına gelen Salvia cinsi çok eski zamanlardan beri pek çok farklı amaç için kullanılmaktadır. Bu cins dünya çapında hem doğadan toplanan hem de yetiştiriciliği yapılan tıbbi ve aromatik bitki türlerini içermektedir. Türkiye'de 92 taksonla temsil 
edilen Salvia L. türlerinin 47'si endemik olup, bu türlerin büyük kısmı Akdeniz ve İran-Turan fitocoğrafik bölgelerinde dağılım göstermektedir (Güner ve ark., 2012). Salvia türlerinden genellikle hidrodistilasyon yöntemi ile uçucu yağ elde edilir. $\mathrm{Bu}$ cinsin fitokimyası ve biyoaktivitesine duyulan ilgi nedeniyle çok sayıda araştırma gerçekleştirilmiştir (Elmas ve Elmas, 2021). Araştırmalarda Salvia cinsinin yapısında yaşamsal faaliyetler için gerekli primer metabolitlerin (aminoasitler, basit şekerler, basit karakterli lipitler ve yağlar) yanı sıra bu bileşiklerden özel metabolik yollarla üretilen ve biyosentez yollarına göre sınıflandırılan sekonder metabolitlerin bulunduğu anlaşılmıştır (Bourgaud ve ark., 2001). Bu sekonder metabolitleri terpenoidler, flavonoidler, steroidler ve diğer fenolik bileşikler oluşturmaktadır. Salvia L. cinsi ile yürütülen çalışmalarda şimdiye kadar 160'tan fazla polifenol (Lu ve Foo, 2002), 450 triterpenoid (Topçu, 2006) tanımlanmış olup; flavonoid, terpenoid ve monoterpenler gibi bileşenlerin bitkilerin daha çok toprak üstü kısımlarında bulunduğu, diterpenoidlerin ise kök kısımlarında bulunduğu bildirilmiştir (Hatipoğlu, 2017). Çalışmalar, doğal yetişen/yetiştirilen Salvia L. türlerinde agronomik ve teknolojik özelliklerin bitkinin ontogenetik evresinden, hasat zamanından, çevresel koşullardan (biyotik ve abiyotik stres koşulları), coğrafi koşullardan (lokasyon, rakım, yön), iklimsel koşullardan, farklı tarım uygulamalarından ve genetik faktörlerden etkilendiğini göstermektedir (Gül ve ark., 2002; Başyiğit ve Baydar 2016; Elmas, 2019; Y1lmaz, 2019).

\subsection{Salvia officinalis $\mathbf{L}$.}

Salvia officinalis türü 60-100 cm arası uzunlukta, beyaz, mavi veya mor çiçekli, yaprakları gümüş renkli, tüylü ve basit, çok yıllık ve yarı çalımsı bir bitkidir. Tohumları yuvarlak, kahverengi, bin tane ağırlığı ortalama 7,6 gramdır (Ceylan, 1996). Salvia officinalis uçucu yağı \%1-2.5 arasındadır ve ana bileşenlerine göre thujone grubunda yer almaktadır (Başer, 2002; Topçu, 2006). $\mathrm{Bu}$ türün kromozom sayıs1 2n=14'tür (Karousou ve ark., 2000). Salvia officinalis spp. lavandulifolia Gams, Salvia officinalis spp. minor Gams ve Salvia officinalis spp. major Gams üç alt türü bulunmaktadır (Ceylan, 1996).

İngiliz Farmakopesi’nde resmi bir ilaç olarak kullanımı kabul edilmiş Salvia officinalis türü, uluslararası ticarette önemli bir yere sahiptir (Topçu, 2006). Tıbbi adaçayı, dişotu ya da meryemiye olarak bilinen bu tür ülkemizde doğal yayılış göstermemektir, ancak dünyada Avrupa'nın güney ve orta kısımları ile Batı Balkanlar'da özellikle Dalmaçya ve Makedonya'da doğal yayılış göstermektedir (Güner ve ark., 2012). Bu türün, Almanya, Güney Fransa, Macaristan, Rusya ve Amerika'da olduğu gibi ülkemizde de yetiştiriciliği yapılmaktadır. Şekil 1'de Salvia officinalis 
bitkisi yetiştiriciliğinin ülkemizde yapıldığı iller ve ilçeler işaretlenmiştir. Adana (Ceyhan, Sarıçam), Antalya (Demre, Gazipaşa, Korkuteli), Denizli (Acıpayam, Bekilli, Buldan, Güney, Merkezefendi, Pamukkale, Tavas, Çal), Düzce (Gölyaka, Merkez, Çilimli), Eskişehir (İnönü), Karaman (Sarıveliler), Kayseri (Yeşilhisar), Kütahya (Altıntaş, Aslanapa, Emet, Hisarcık, Merkez, Simav, Çavdarhisar, Şaphane), Manisa (Salihli), Muğla (Datça, Fethiye, Marmaris, Milas, Ortaca, Ula, Yatağan), Tekirdağ (Süleymanpaşa, Şarköy), Uşak (Sivaslı) ve İzmir (Kemalpaşa)'de 20122019 yılları arasında farklı miktarlarda Salvia officinalis yetiştiriciliği yapılmıştır (TÜİK, 2021).

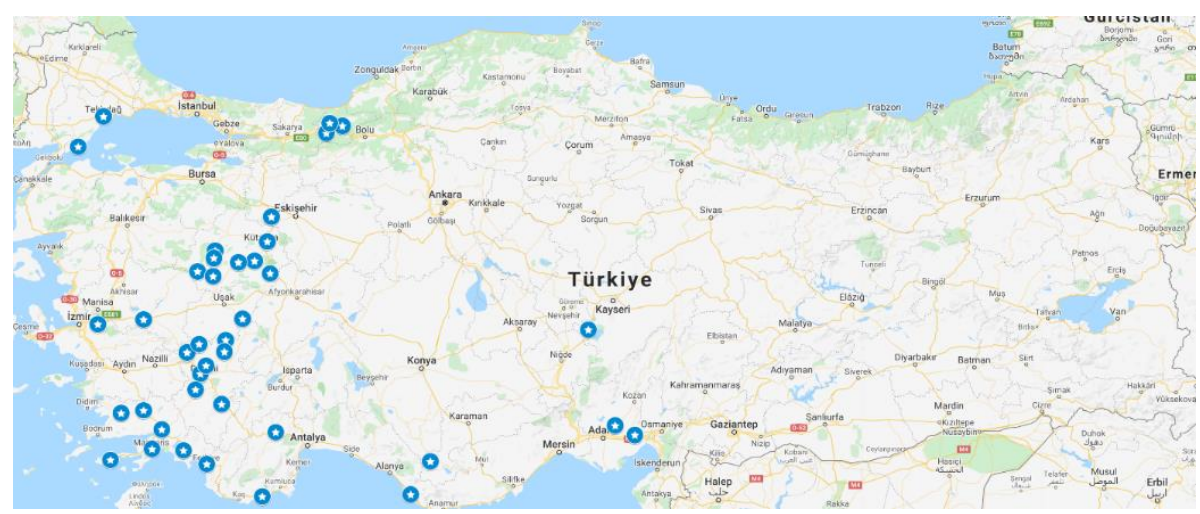

Şekil 1. Salvia officinalis L.'nin Türkiye'de yetiştiriciliğinin yapıldığı yerler (TÜİK, 2021).

\subsection{Salvia fruticosa Mill.}

Ülkemizde Anadolu adaçayı olarak bilinen Salvia fruticosa dünyada Balkanlar, İtalya, Sirenayka, Sicilya ve Suriye'nin batısında; ülkemizde ise Şekil 2'de gösterildiği üzere Batı Anadolu (İzmir), Kuzeybatı Anadolu (Balıkesir, Tekirdağ) ve Güneybatı Anadolu'da (Antalya, Aydın, Muğla) doğal yayılış göstermektedir. Çok yıllık bir bitki olan Salvia fruticosa, boyu 160 cm'ye kadar erişebilen, maki ya da frigana kireçtaşı kayalıklar arasında, 0 ila 700 m rakımda yetişebilen, Mart-Mayıs aylarında çiçeklenen, dalları grimsi yeşil renkli tüyler ile örtülü bir türdür (Güner ve ark., 2012; Elmas, 2019). Botanik olarak Salvia officinalis'e benzer ancak bu türde esas yaprakların yanında bir veya iki tarafı az veya çok gelişmiş yan yaprakçık bulunması ve biraz daha çalı formuna yakın olmasıyla Salvia officinalis'ten ayrılır, ayrıca uçucu yağı daha keskin kokuludur. Tohumları kahverengi, bin tane ağırlıkları ortalama olarak 4 g'dır (Bayram ve Sönmez, 2006). Yetiştiği lokasyona göre uçucu yağı \%0.9-5.15 arasında değişebilmektedir (Karık ve Sağlam, 2017). Çalışmalarda Salvia fruticosa türünün uçucu yağında 1,8-cineole bileşeninin etken madde olduğu ve ana bileşenlerine göre $\mathrm{CiCa}$ (1,8 cineole/camphor) grubunda yer aldığg belirtilmiştir (Başer, 2002). $\mathrm{Bu}$ türün diploid kromozom sayısı 2n=14 olarak belirlenmiştir (Martin ve ark., 2011). Yapılan 
değerlendirmelerde ülkemizde Salvia fruticosa'nın zarar görebilir kategorisinde yer aldığ belirtilmiştir (İpek ve Gürbüz, 2010).

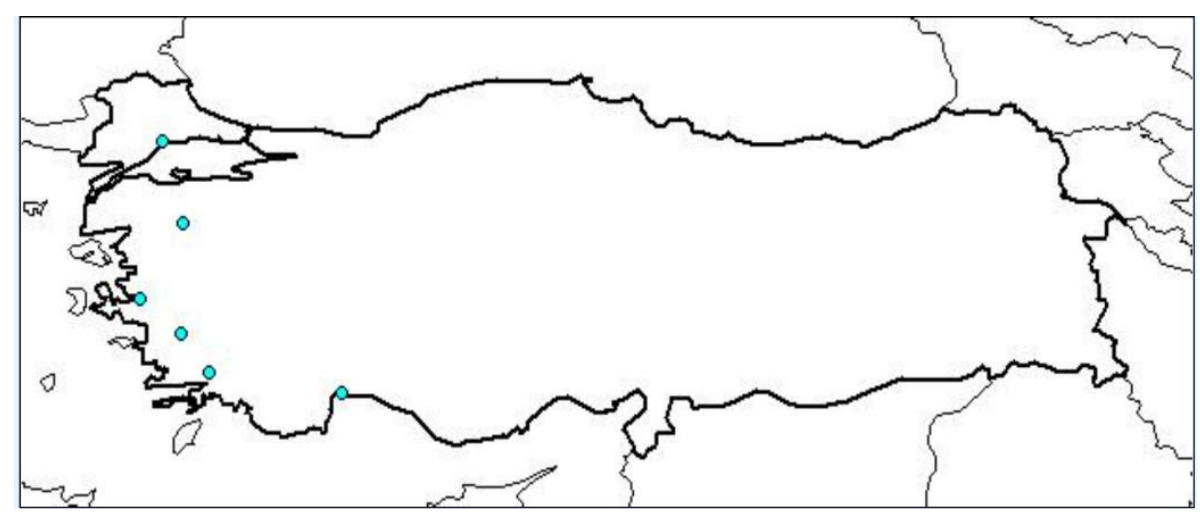

Şekil 2. Türkiye'de Salvia fruticosa'nın doğal yayılış gösterdiği yerler (Güner ve ark., 2012).

\subsection{Salvia tomentosa Mill.}

Şalba, büyük çiçekli adaçayı gibi farklı isimlerle bilinen Salvia tomentosa Türkiye'de hem iç hem dış ticarette önem arz etmektedir. Dünyada Kırım, Lübnan, Latakya, Balkanlar ve Ermenistan'da doğal yayılış göstermekte; Almanya, Güney Fransa ve Macaristan'da ise yetiştiriciliği yapılmaktadır. Salvia tomentosa Şekil 3'te belirtildiği üzere ülkemizin Adana, İstanbul, Zonguldak, Ankara, Antalya, Bursa, Eskişehir, Gümüşhane, Hatay, Isparta, İzmir, Kütahya, Kahramanmaraş, Sinop, Karaman illerinde doğal yayılış göstermektedir. Pinus brutia (Kızılçam) ve Pinus nigra (Karaçam) ile ortak yaşayan, Quercus pubescens (Tüylü meşe) makisi ve kireçtaş1 yamaçlarda 90-2000 m rakımda yetişebilen, 50-100 cm kadar uzayabilen bir türdür. Çiçekleri diğer Salvia türlerine göre daha büyük ve genellikle mor renkli, çok yıllık, odunsu ot formundadır (Dumanoğlu ve Mokhtarzadeh, 2020). Nisan ayı ilk çiçeklenme zamanı, Ağustos ayı son çiçeklenme zamanıdır (Güner ve ark., 2012; Tuna, 2019). Tohumları kısa boyutlarda ve oval bir yapıya sahiptir, bin tane ağırlıklarının yaklaşık 7,15 g olduğu belirtilmiştir (Dumanoğlu ve Mokhtarzadeh, 2020). Uçucu yă̆ oranı \%0,7-3,5 arasında değişiklik göstermekte ve ana bileşenlerine göre pinene grubunda yer almaktadır (Başer, 2002; Karık ve ark., 2013). Bu türün diploid kromozom sayısı ise $2 \mathrm{n}=16$ olarak belirlenmiştir (Nakipoğlu, 1993). 


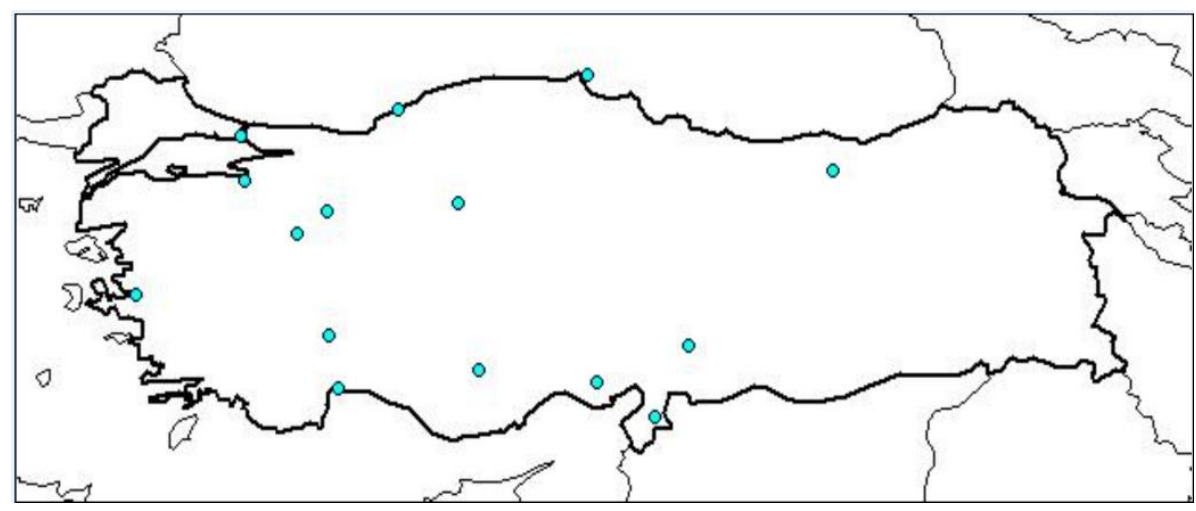

Şekil 3. Salvia tomentosa Mill.'in Türkiye'de doğal yayıllıs gösterdiği bölgeler (Güner ve ark., 2012).

\section{Adaçayı Yetiştiriciliği}

\section{1. İklim ve Toprak İstekleri}

Fide döneminde yüksek miktarda neme ihtiyaç duyan adaçayı, ilerleyen gelişme döneminde sıcağa oldukça dayanıklı ancak aşırı soğuk ve donlara karşı dayanıksızdır. Kış mevsiminde ılıman iklim bölgelerinde ve rüzgarlardan korunan bölgelerde adaçayı üretiminin yapılabileceği belirtilmiştir (Bağdat, 2006). Adaçayı yetiştiriciliği için taban suyu seviyesinin yüksek olmadığı, alkali, iyi drenajlı, geçirgen ve besin elementleri bakımından zengin, tınlı-kumlu, kumlu-tınlı, kireç içeriği zengin topraklar idealdir (Bayram ve Sönmez, 2006). Ekim nöbeti planlamasında Bayram ve Sönmez (2006), baklagillerden veya ahır gübresi verilmiş bir çapa bitkisinden sonra gelmesini önermiş, Bağdat (2006), ise lahana, havuç, çilek, domates ve mercanköşkle uyum sağladığını belirtmiştir. Adaçayında en yüksek yağ verimi ise sıcak, bol güneşli, kurak, düşük rakımlı ve eğimli araziler üzerindeki bölgelerden elde edilmektedir (Dinçer, 2007).

Tıbbi ve aromatik bitkilerde morfolojik, anatomik, fizyolojik ve biyokimyasal özelliklerin ortaya konmasında bitkinin genetik profili önemli rol oynamaktadır. Skoula ve ark., (2000), Girit'in farklı popülasyonlarından topladığı aynı tür adaçayını, tarlada ve saksılarda sabit deneysel koşullar altında yetiştirmiş, klonlarda genetik profillerine karşılık gelen morfolojik farklılıkların yanı sıra uçucu yağın fenolik verimi, kompozisyonu gibi bazı varyasyonlar belirlemiştir. Elmas (2019), Muğla yöresinde farklı popülasyonlardan topladığı adaçayı örneklerinde morfolojik, kimyasal ve moleküler özellikler açısından hem popülasyon içi hem de popülasyonlar arasında geniş varyasyonlar görüldüğünü belirtmiştir. Bu geniş varyasyonların nedeni olarak, fenotip ve genotip arasında gen ekspresyonu, gen regülasyonu gibi bir dizi karmaşık bağlantı olabileceği gibi, bitkilerin morfolojik karakterlerinin çevre ile birlikte değişebileceği ve doğal seleksiyon süresince türler arasındaki gen alışverişleri olabileceğini varsaymıştır. Salvia L.'de genotipleri 
tanımlamanın, morfolojik benzerliğin fazla olması ve bu türler arasında doğal hibridizasyonun yaygın olması nedeniyle karmaşık olduğu belirtilmektedir (Karaca ve ark., 2008). Ancak yetiştiriciliği yapılacak adaçayı türünde genotipin tanımlanması, tarımsal açıdan önemli genlerin belirlenmesi, genetik çeşitliliğin belirlemesi, çevresel ve iklimsel değişiklerin gen yapılarında meydana getirdiği değişikliklerin ortaya konulması tarımsal başarı sağlamak için önemlidir.

\section{2. Üretim Tekniği ve Ekim}

T1bbi ve aromatik bitkilerin belli bir standartta üretilebilmesi için kültürü yapılacak bitki tohumlarının genel yapısı, ekimi veya fidanların dikiminde sıra arası mesafe, tarımsal işlem basamakları, kullanılması gereken alet ve makinelerin seçimi gibi gerekli bazı verilerin bilinmesi gereklidir. Adaçayı, hem generatif hem de vejetatif olarak üretilebilen bir bitkidir. Generatif üretim tohumlarla sağlanırken, vejetatif üreme çelikler sayesinde yapılır (Özcan ve ark., 2014). Generatif üretimde, tohumların ekim zamanı için ilkbahar veya sonbahar mevsimleridir. Adaçayı tohumu ekimi için en uygun koşullar Ege bölgesi için sonbahar, karasal iklimler için ilkbahardır. Tohumlar iyi hazırlanmış tarlaya doğrudan ekilebilir, bunun için bir dekara gerekli tohum miktarı 2-5 kg arasıdır (Bağdat, 2006; Bayram ve Sönmez, 2006). Ancak adaçayında tohum tutma oranının son derece düşük olduğu ifade edilmiştir (Arslan ve ark, 1995). Tohumların müsilajımsı tabaka ile kaplı olması ve dormansi söz konusu olduğundan gelişme genellikle yavaş olmakta veya tohum çimlenme sorunları oluşabilmektedir. Bu nedenle adaçayında tohum çimlendirme çalışmaları bu türe ait üretim stratejilerinin belirlenmesinde büyük önem taşımaktadır (Özcan ve ark., 2014).

Farklı araştırmacılar tarafından yapılan çalışmalar, adaçayı yetiştiriciliğinde uygun dozajda bazı hormonların kullanılmasının, tohum çimlenmesi ve çeliklerin köklendirilmesinde önemli bir rol oynadığını ortaya koymuştur. Bunlar arasında en çok oksin grubu büyüme düzenleyiciler içerisinde yer alan Indol Bütirik Asit (IBA) köklendirmede yaygın olarak kullanılmaktadır. IBA dışında, Indol-3-Asetik Asit (IAA), Naftalen Asetik Asit (NAA) ve Gibberellik Asit (GA 3 ) “Büyümeyi Düzenleyici Maddeler” olarak kullanılabilmektedir (Hartmann ve ark., 1997; Kara ve ark., 2011). Adaçayı tohumlarının çimlenme, çıkış performanslarının iyileştirilmesi ve kalitelerinin arttırılması amacıyla gerçekleştirilen bir çalışmada, Salvia officinalis tohumlarının Polimer $+\mathrm{GA}_{3}$ ve Priming+Polimer+KNO 3 uygulamasında en yüksek oranda çimlenme gösterdiği, Salvia fruticosa tohumlarının $\mathrm{GA}_{3}$ ve Polimer+GA 3 uygulamalarında en yüksek oranda çimlenme gösterdiği, ayrıca her iki türde de $\mathrm{KNO}_{3}$ uygulamasının tohumların en kısa sürede ortalama çimlenme zamanına ulaşmasını sağladığı bildirilmiştir (Sönmez ve ark., 2019). Farklı kimyasal uygulamaların ve ön 
işlemlerin (ön kurutma, ön üşütme ve ön işlemsiz) farklı adaçayı tohumlarının çimlenme gücüne etkileri araştırıldığı başka bir çalışmada, Salvia officinalis türü için her üç ön işlemin kullanılabileceği, Salvia fruticosa'da ön üşütme işlemi, Salvia tomentosa'da ise ön kurutma işleminin tercih edilmesi belirtilmiş; en iyi sonucun Salvia officinalis ve Salvia fruticosa türlerinde gibberellin uygulamasından, Salvia tomentosa türünde ise hem gibberellin hem de etilen uygulamalarından elde edildiği belirtilmiştir (Özcan ve ark., 2014).

Adaçayı yetiştiriciliğinde ilk yıllarda yabancı ot mücadelesi yüksek tarım maliyetlerinden birini oluşturmaktadır. Yabanc1 ot mücadelesi, mümkünse herbisit kullanmadan adaçayı fideciklerinin toprağı siperleyip diğer otların gelişip büyümesine firsat vermeyecek seviyeye gelene kadar devam etmelidir. Bu nedenle bu süreyi kısaltmak ve maliyeti düşürmek için adaçayı fideciklerinin hızlı gelişimi önem taşımaktadır (Abacıoğlu, 2019). Bununla ilgili olarak yapılan bir çalışmada farklı hormon ve dozlarının morfolojik özelliklere etkisi araştırılmış ve Salvia officinalis tohumlarında çimlenme yüzdesinde ve yaprak sayısında en yüksek değerler 1000 ppm dozunda NAA hormonundan elde edilirken, en yüksek fide boyunun 5000 ppm IAA uygulamasindan, en yüksek kök uzunluğu ve bitki boyunun 3000 ppm dozunda NAA hormonundan elde edildiği bildirilmiştir (İzci, 2020). Benzer başka bir çalışmada, Salvia officinalis tohumlarında hormon uygulamalarının çeşidi ve dozuna göre farklılık göstermekle beraber çimlenme yüzdesi ve kök sayısında olumlu etkilerinin olduğu, yaprak eni için 5000 ppm IBA ve 1000 ppm NAA; yaprak boyu için 5000 ppm IBA; yaprak sayısı için 200 ppm GA 3 ; dalsız gövde boyu için 100 ppm IAA uygulaması ile en yüksek değerlere ulaşıldığı saptanmıştır (Abacıoğlu, 2019).

Bunlara ek olarak, Salvia officinalis türünde nano boyutlu titanyum dioksit $\left(\mathrm{TiO}_{2}\right) 60 \mathrm{mg} \mathrm{L}-1$ uygulaması (Feizi ve ark., 2013) ve 125 mT'lik sabit manyetik alan maruziyeti uygulaması ile tohumların çimlenme oranlarında yüksek başarı elde edildiği bildirilmiştir (Flórez ve ark., 2012).

Adaçayı, generatif üretimine alternatif olarak vejetatif olarak çoğaltılabilmektedir. Vejetatif üretimde 1 dekar alan için yaklaşık 200-300 g tohum önce fideliklere ekilir, elde edilen fideler 5-6 yaprak olunca veya $10-15 \mathrm{~cm}$ boyuna geldiğinde tarlaya aktarılır. Hem tohum ekiminden hem de fide dikiminden önce toprak analizlerinin yapılmış olması ve toprağın ihtiyacına göre gübreleme yapılması önerilmektedir. Fidelerin tarlaya aktarılmasından önce varsa yabancı ot probleminin ortadan kaldırılmış olması, sonrasında tarlada derin sürüm yapılması, diskaro-tırmık veya kazayağı tırmık ile toprak yüzeyinin düzeltilmesi gerekir. Fidelerin dikiminden sonra can suyu verilir. Fidelerin dikimi için en uygun zaman, bölgelere göre değişmekle birlikte don riskinin olmadığı, Mayıs-Haziran veya Ekim-Kasım aylarıdır (Bağdat, 2006; Bayram ve Sönmez, 2006). Salvia 
officinalis bitkisinin vejetatif üretiminde IBA uygulamasının adaçayı çeliklerinde, kök oluşumu ve köklenmeyi önemli derecede etkilediği, en fazla kökçük oluşumu, en yüksek köklenme oranı, kök sayısı ve en uzun köklerin IBA uygulamasından elde edildiği bildirilmiştir (Ayanoğlu ve Özkan, 2000; Kara ve ark., 2011).

Tarımsal üretimde birim alandan daha fazla verim alabilmenin şartlarından biri de uygun bitki sıklığının sağlanmasıdır. Çalışmalar genellikle birim alandaki bitki sayısının artmasıyla, bitki başına verimin azaldığını, toplam verimin ise arttığını; birim alandaki bitki sayısının azalmasıyla bitki başına verimin arttığını, ancak birim alandan elde edilen toplam verimin azaldığını bildirmektedir (Öz, 2002). Bu nedenle adaçayı yetiştiriciliğinde uygun bitki-alan kritik sınırının belirlenmesi ve bunun bitki verimi, kalitesi ile uçucu yă̆ oran ve içeriği üzerine etkisinin bilinmesi önem taşımaktadır. Adaçayında fidelerin dikimi çapa makinesi ile yapılacaksa sıra arası mesafesinin 100 $\mathrm{cm}$, sıra üzeri mesafesinin $40 \mathrm{~cm}$; el ile yapılacaksa sıra arası $50 \mathrm{~cm}$, sira üzeri mesafenin 20 ya da $40 \mathrm{~cm}$ olması önerilmektedir (Tıbbi Adaçayı Yaygınlaştırma Raporu, 2018). Ancak bu durum yetiştiricilik yapılacak bölgenin ekolojik koşullarına ve mekanizasyon durumuna göre değişebilir. Bornova ekolojik koşullarında tıbbi adaçayında $30 \mathrm{~cm}$ sıra arası mesafede, $60 \mathrm{~cm}$ sıra arası mesafesine göre daha yüksek verim elde edildiği bildirilmiştir (Bayram ve Sönmez, 2006). Siirt ekolojik koşullarında yetiştirilen Salvia officinalis bitkisinde farklı sıra üzeri mesafelerinin bazı kalite kriterlerine ve uçucu yağ kompozisyonuna etkilerini incelemiş, bitki boyunda ve uçucu yağ oranında en yüksek değerin $20 \mathrm{~cm}$ sıra üzeri mesafesinden; dal sayısında en yüksek değeri $60 \mathrm{~cm}$ sıra üzeri mesafesinden alındığı bildirilmiştir (Özek, 2019).

Çalışmalar adaçayının generatif ve vejetatif üretiminde agronomik özellikler bakımından varyasyonlar oluştuğunu göstermektedir. Adaçayı yetiştiriciliğinde en iyi sonucun alınabilmesi için farklı hormon ve hormon kombinasyonlarının farklı dozları ile çalışmaların çeşitlendirilip artırılarak devam ettirilmesi gereklidir.

\subsection{Bakım ve Gübreleme}

Adaçayı yetiştiriciliğinde çapalama, sulama gibi bakım işlemleri verim ve kalite açısından oldukça önemlidir. Çapalama, yabancı ot mücadelesi ile toprağın havalandırılmasını ve neminin korunmasını sağlar. Adaçayı bitkileri uygun toprak ve hava sıcaklık koşullarında ekimden yaklaşık 2-3 hafta sonra toprak yüzeyine çıkmaya başlar. Çıkış gözlenmediği takdirde toprakta kaymak tabakası oluşmuşsa kaymak kırma işlemi yapılır. Bitki yüksekliği 3-4 cm’ye eriştiğinde gölgeleme ve sıklıktan dolayı verim kaybı olmaması için seyreltme işlemi uygulanmalıdır. Yetiştirme 
ortamında gelişen yabancı otlar, yetiştiriciliği yapılan bitkilerle besin elementleri, su ve 1şık için rekabete girerek veya bunlara ortak olarak bitkinin büyüme ve gelişmesine engel olabilir. $\mathrm{Bu}$ nedenle bitki yüksekliği 5-7cm'ye eriştiğinde yabancı ot mücadelesi için ilk çapa yapılır. Adaçayında ilk yıl vejetatif gelişim yavaş olduğundan bu işlem birkaç kere tekrarlanmalıdır. İkinci çapalamada ise kök boğazı doldurulur. Boğaz doldurma işlemi ile hem bitkilerin soğuktan zarar görmesi engellenir hem de bitkiler toprağa daha sağlam tutunur, kökleri daha derine salınır böylelikle toprak altı organlarının gelişimi ile su ve besin maddelerinin alımı sağlanır. Çapalama işleminin sıklığı toprağa, yabancı ot gelişimine ve ekolojik koşullara göre değişebilir. Bir diğer bakım işlemi ise sulamadır. Adaçayının vejetasyon süresince bitki toprağa tutuna kadar sulanması önerilmektedir. Sulama karık, salma, damla sulama veya yağmurlama olarak yapılabilir. Adaçayında yağmurlama, karık ve salma sulama yöntemlerinin dezavantajları, hastalık etmenlerinin yayılmasının kolay olması, sslanan bitki yapraklarında kalan damlacıkların mercek etkisi görerek yapraklarda güneş yanıkları oluşturması ve bitkinin herba kalitesini düşürmesidir. Ancak damla sulama yönteminde su, bitki yapraklarına değil doğrudan toprağa verilir hastalıklar daha nadir görülür, buharlaşma kaybı diğer yöntemlere göre daha azdır ve suyun homojen dağılımı sağlanır (Bayram ve Sönmez, 2006; Tibbi Adaçayı Yaygınlaştırma Raporu, 2018).

Tıbbi ve aromatik bitki üretiminde verim ve kalitenin artırılabilirliğini sağlayan en etkin araçlardan biri gübrelemedir. Gübrelemede bitkinin yaşı dikkate alınarak dengeli kullanım sağlanmalıdır. Akdeniz kökenli bir bitki olan adaçayının kış soğuklarına karşı mukavemetinin artması için potasyum sülfat gübresi uygulanmalıdır. Bitkinin fosfor gübresine gereksinimi fazla olmamakla beraber, çiçeklenmeyi ve aroma yoğunluğunu arttırdı̆̆ı için verilmesi önerilmektedir (Bayram ve Sönmez, 2006). Gübreler içerisinde önemli makro bitki besin elementlerinden biri azottur (Özyazıcı ve ark., 2015). Literatürde adaçayı türlerinde azotun verim, verim komponentleri ve kalite üzerindeki etkisini ortaya koymak için çalışmalar yürütülmüştür. Bu çalışmalarda farklı ekolojik koşullarda yetiştirilen Salvia officinalis'te azotlu gübrelemenin yeşil herba, drog herba, yeşil yaprak, drog yaprak, yeşil sap ve drog sap verimlerinde istatistiksel yönden önemli olduğu bildirilmiştir (Ceylan ve ark., 1979; Ceylan ve ark., 1990; Karaaslan, 1994; Koç, 2000; Sönmez ve Bayram, 2017). Ancak, Koç (2006), Salvia officinalis'te azot uygulamasının bitki boyu ve drog herba verimine istatistiksel açıdan önemli bir etkisinin olmadığını, kükürt uygulamalarının ise bitki boyu ve yeşil herba verimini azalttığını tespit etmiştir (Koç, 2006).

Adaçayında uçucu yağ miktarı üzerine toprak yapısı, tekstür, iklim, sulama, dikim sıklığı, hasat zamanı gibi birçok faktörün yanında gübrelemenin de etkili olduğu bilinmektedir (Koç, 2006). 
Karaaslan, (1994), Salvia officinalis'te $15 \mathrm{~kg} / \mathrm{da}$ N doz uygulaması ile, Koç, (2000), aynı türde ikinci yılda $5 \mathrm{~kg} / \mathrm{da} \mathrm{N}$ uygulaması ile uçucu yağda en yüksek verimi elde ettiğini bildirirken, bazı araştırmacılar ise azotlu gübrelemenin Salvia officinalis'te uçucu yă̆ oranı üzerinde etkisinin belirgin olmadığını belirtmişlerdir (Ceylan ve ark., 1979; Koç, 2006). Katar ve ark., (2019), Salvia fruticosa'da $10 \mathrm{~kg} / \mathrm{da} \mathrm{N}$ dozunda uçucu yağda en yüksek verimi elde edildiğini bildirmiş, Yılmaz (2019), aynı türde $10 \mathrm{~kg} / \mathrm{da} \mathrm{N}$ dozu ile en yüksek uçucu yağ oranı ile $15 \mathrm{~kg} / \mathrm{da} \mathrm{N}$ dozu ile en yüksek uçucu yağ verimi elde edildiğini belirtmiştir.

Adaçayında verim artışı için kullanılacak kimyasalların toksik etki yapmayacak şekilde ayarlanması gerekir. Araştırmacılar, Tokat ekolojik şartlarında Salvia officinalis’te yeşil herba ve drog yaprak verimi için $15 \mathrm{~kg} / \mathrm{da}$ azot, drog herba verimi için $10 \mathrm{~kg} / \mathrm{da}$ azot uygulamasını önerirken, (Koç, 2000), Eskişehir ekolojik koşullarında Salvia fruticosa yetiştiriciliğinde drog yaprak ve uçucu yağ verimi için $10 \mathrm{~kg} /$ da azot dozu önerilmiştir (Katar ve ark., 2019). Aydın ekolojik koşullarında yetiştirilen Salvia fruticosa' da bitki boyunda en yüksek değer $10 \mathrm{~kg} / \mathrm{da} \mathrm{N}$; drog herba, yeşil herba, yeşil yaprak ve drog yaprak verimlerinde en yüksek değerlerin $15 \mathrm{~kg} / \mathrm{da}$ uygulamasından elde edildiği bildirilmiştir (Yılmaz, 2019). Çanakkale'de yetiştirilen aynı türde ise en yüksek drog herba verimi, drog yaprak verimi ve uçucu yağ veriminin sulu koşullarda $6 \mathrm{~kg} / \mathrm{da} \mathrm{N}$ uygulamasından, kuru koşullarda ise $18 \mathrm{~kg} / \mathrm{da} \mathrm{N}$ uygulamasından elde edilmiştir (Turhan, 2020).

Bazı araştırmacılar ise bitki üretiminde kullanılan kimyasal gübrelerin insan sağlığı ve çevre üzerinde oluşturduğu çeşitli olumsuz etkiler ile birlikte getirdiği ekonomik maliyete dikkat çekmişlerdir. $\mathrm{Bu}$ nedenle adaçayı yetiştiriciliğinde verim ve kaliteyi arttırmak amacıyla kullanılan kimyasal gübrelerin yerine organik gübrelerin kullanılmasının ekolojik üretime uygunluk bakımından önem arz ettiğini vurgulamışlardır (Kocabaş ve ark., 2007; Kaplan ve ark., 2007; Katar ve ark., 2019). Farklı organik gübre uygulamalarının Salvia fruticosa bitkisinin besin elementi ve uçucu yağ oranı üzerine olan etkilerinin araştırıldığı bir çalışmada, en yüksek N içeriğini ve uçucu yağ oranının tavuk+koyun gübresi kombinasyonunda, P içeriğinde en yükssek değerin koyun+sığır gübresi uygulamasında ve en yüksek $\mathrm{K}$ içeriğinin tavuk gübresi uygulamasında tespit edildiği bildirilmiştir. Organik gübrelerin uygulandığı bitkilerin kontrollere göre gelişimleri hızlı ve verimleri yüksek olduğu için, bu bitkilerdeki $\mathrm{Ca}, \mathrm{Mg}, \mathrm{Fe}$ ve $\mathrm{Zn}$ içeriklerinde düşüş görülmüştür. Çalışmada ayrıca Salvia fruticosa bitkisinin uçucu yağ içeriği ile bitkinin N, P, K içeriği arasında pozitif yönde bir korelasyon elde edilirken; $\mathrm{Ca}, \mathrm{Mg}$ içeriği arasında negatif bir korelasyon olduğu bildirilmiştir (Kocabaş ve ark., 2007). Benzer başka bir çalışmada Salvia fruticosa'da farklı organik gübre uygulamaları yapılan bitkilerde drog herba ağırlığı, uçucu yağ içeriği ve bitki başına düşen 
yağ miktarına kontrol bitkileriyle karşılaştırıldığında istatistiksel olarak anlamlı bir artış görüldüğü saptanmıştır. En yüksek drog herba ağırlığı ve uçucu yağ miktarının kanatlı gübresi uygulanan bitkilerden elde edildiği bildirilmiştir (Kaplan ve ark., 2007). Organik gübre uygulamalarının Salvia fruticosa uçucu yağının kimyasal bileşimi üzerine etkisi de belirlenmiş, buna göre tavuk+koyun gübresi kombinasyonundan en yüksek uçucu yağ verimi elde edilmiştir (Kocabaş, 2010). Çalışmalar organik gübre uygulamalarının adaçayı uçucu yağ verimini arttırdığı ve bitki gelişimi üzerinde pozitif etkisinin olduğu göstermiştir. Elde edilen bulgular adaçayının ekolojik üretiminde organik gübrelemelerle de verim ve kalitede önemli artışların elde edilebileceğini desteklemektedir.

\subsection{Hasat ve kurutma}

T1bbi ve aromatik bitki yetiştiriciliğinde yüksek verim ve istenen kalitede ürün elde etmek için, bitkinin ihtiyaç duyduğu ekolojik şartlarda yetiştirilmesinin yanı sıra uygun hasat zamanlarının belirlenmesi gerekir. Çalışmalarda çok yıllık bir bitki olan ve vejetasyon süresince birden fazla biçim yapılabilen adaçayında hasat zamanı, kurutma teknikleri ve biçim yüksekliğinin, verim ve kalite üzerinde etkili olduğu gösterilmiştir (Ekren ve ark. 2007; Özkeskin, 2019). Bağdat (2006), adaçayında en uygun hasat zamanının çiçeklenme başlangıcı olduğunu belirtirken, Bayram ve Sönmez (2006), ise çiçeklenme dönemini önermişlerdir. Bolu ekolojik koşullarında yetiştirilen Salvia officinalis ve Salvia tomentosa türlerinde, bitki boyunda her iki türde de tam çiçeklenme zamanı en yüksek değerlere ulaşılırken, yeşil herba veriminde her iki türde \%50 çiçeklenme zamanında ve drog herba veriminde ise ortalama en yüksek değerlerin Salvia officinalis'te \%50 çiçeklenme zamanında, Salvia tomentosa' da ise tam çiçeklenme zamanında yapılan hasattan elde edildiği bildirilmiştir (Şenkal ve ark. 2012). Tokat-Kazova koşullarında ise Salvia officinalis'in sonbahar biçiminde bitki boyu, yeşil herba, kuru herba, kuru yaprak verimleri ve kuru madde oranının yaz dönemindekine göre daha yüksek çıktığı belirtilmiştir (Özkeskin, 2019). Isparta'da yetiştirilen Salvia officinalis'te ise en yüksek taze herba verimi Eylül, drog herba verimi Temmuz, drog yaprak verimi Ağustos ayında belirlenmiştir (Başyiğit ve Baydar, 2016). Aydın ekolojik koşullarında Salvia fruticosa' da çiçeklenme sonrası hasat yapılmasının yaprak boyu ve enini olumlu yönde etkilediği, yeşil herba, yeşil yaprak ve drog herba verimlerinde en yüksek verimin tam çiçeklenme zamanında yapılan hasattan elde edildiğini, en yüksek yeşil yaprak oranının ise çiçeklenme öncesi yapılan hasattan elde edildiği vurgulanmıştır (Yılmaz, 2019).

Farklı hasat zamanları sadece tarımsal özellikleri değil, uçucu yağ oranı ve bileşenleri gibi kimyasal özellikleri de etkilemektedir. Isparta ekolojik koşullarında yetiştirilen Salvia officinalis'te 
en yüksek uçucu yă̆ oranı Ağustos ayında (Başyiğit ve Baydar 2016), Eskişehir ekolojik koşullarında çiçeklenme öncesi dönemde (Katar ve ark., 2018), Tokat-Kazova koşullarında ise yaz döneminde yapılan hasatlardan elde edildiği (Özkeskin, 2019); bu türün ana bileşeni $\alpha$-thujonun en yüksek değerleri Isparta koşullarında ilkbahar aylarında (Başyiğit ve Baydar 2016), Eskişehir koşullarında tam çiçeklenme döneminde (Katar ve ark., 2018), Tokat-Kazova koşullarında ise yaz döneminde yapılan hasatlardan (Özkeskin, 2019) elde edilmiştir. Gökova, Köyceğiz ve Nif Dağı'nda doğal olarak yetişen Salvia fruticosa'da ise uçucu yağ oranı ve 1,8-cineolün en yüksek değeri Haziran ayının son haftası ile Temmuz ayının ilk haftasında elde edilirken (Gül ve ark., 2002), Muğla Fethiye'de yetişen Salvia fruticosa'da ana bileşenin en yüksek değeri çiçeklenme öncesi dönemde, Salvia tomentosa'da ise ana bileşen $\alpha$-pinene için en yüksek değer çiçeklenme sonrası dönemde belirlenmiştir (Önal, 2015).

Adaçayında verimi etkileyen bir diğer unsur biçim yüksekliğidir. Adaçayında biçim, bağ makası, tırpanlarla yapılabileceği gibi alanın büyüklüğüne bağlı olarak biçme makineleri ile de yapılabilir (Bağdat, 2006; Bayram ve Sönmez, 2006). Bağdat, (2006), ilk yıl vejetatif aksan yeterince gelişmişse biçim yüksekliğinin 8-10 cm olmasını, Bayram ve Sönmez (2006), ise 5-10 cm olması gerektiğini belirtmişlerdir. İzmir Bornova koşullarında Salvia officinalis’te yapılan bir çalışmada, biçim yüksekliğinin artmasının bitkide sürgün gelişimini teşvik ettiği, böylelikle bitkilerin hem daha çabuk büyümesine hem de daha uzun boylu olmasına katkı sağladığı bildirilmiş, ideal biçim yüksekliğini $15 \mathrm{~cm}$ olarak belirlemişlerdir (Ekren ve ark., 2007). Başka bir çalışmada ise araştırmacılar aynı türdeki adaçayında yüksek kaliteli bitki ve uçucu yağ verimi elde etmek için, büyüme mevsimi boyunca, toprak seviyesinden 10 ila $15 \mathrm{~cm}$ yükseklikte iki hasat yapılmasını önermişlerdir. İlk hasadın süt olum döneminden olgun tohum oluşumu aşamasında, ikincisinin ise 70-100 gün sonra yapılması gerektiğini, böylelikle bitkilerin iki hasat dönemi arasında ve kış uykusundan önce iyi bir rejenerasyon elde edilebilmesine katkı sağlayacağını bildirmişlerdir (Zutic ve ark., 2003).

Tıbbi ve aromatik bitkiler hasat sonrası yüksek oranlarda su içerebilir. Bitki kalitesinde herhangi bir bozulma oluşturmadan, güvenli depolama sağlayabilmek için bitkideki nemi en kısa sürede ve az enerjiyle nihai nem değerine düşürme işlemine kurutma denir (Polatcı ve Tarhan, 2009). Adaçayı bitkisinde uçucu yağların sentezlendiği ve depolandığı organlar bitkinin dış yüzeyine yakındır, bu nedenle kurutma yöntemleri ve sıcaklıkları bitkinin uçucu yağ oranını ve kompozisyonunu etkilemektedir (Baydar, 2013; Mammadov, 2014; Aydın ve ark., 2019). Adaçayı hasat sonrası yükssek miktarda su içerdiğinden yığın halde bekletilmeleri halinde kızışma sonucu 
kalitede kayıplar olabilir. Bu nedenle özel kurutma alanlarında sererek ve düzenli olarak alt üst edilerek kontrollü koşullarda kurutulmaları önerilmektedir. Yapay kurutmada ise sıcaklığın 35 ${ }^{\circ}$ C'yi geçmemesine dikkat edilmelidir (Bayram ve Sönmez, 2006; Bağdat, 2006). Salvia fruticosa'da farklı kurutma sıcaklıklarının uçucu yağ oranı ve içeriğine etkisinin belirlendiği bir çalışmada en yüksek uçucu yağ oranının $35{ }^{\circ} \mathrm{C}$ sıcaklıkta yapılan kurutmadan; 1,8 cineol oranının ise $65^{\circ} \mathrm{C}$ 'de yapılan kurutmadan elde edildiği bildirilmiştir (Aydın ve ark., 2019). Benzer başka bir çalışmada Salvia officinalis'te ise en yüksek uçucu yağ oranı aynı şekilde $35^{\circ} \mathrm{C}$ sıcaklıkta yapılan kurutmadan, en yüksek $\alpha$-thujon oranının ise taze yaprak örneklerinin ardından $55{ }^{\circ} \mathrm{C}$ sıcaklıkta yapılan kurutmadan elde edildiği bildirilmiştir (Katar ve ark., 2019).

Adaçayında verim, kalite, uçucu yağ oranı ve bileşenlerin çevresel koşullara, genetik faktörlere, yetiştiricilik uygulamalarındaki farklılıklara, biçim yüksekliğine, biçim sayısına ve hasadının yapıldığı gelişim dönemine bağlı olarak değişiklik gösterdiği çalışmalarla desteklenmiştir (Aziz ve ark., 2013; Lakušić ve ark., 2013; Mammadov, 2014).

\subsection{Verim}

Adaçayında verim kriteri genellikle yeşil ve drog herba verimi ile uçucu yăg oranıdır. Adaçayı yetiştiriciliğinde ilk yıl plantasyon yılı olduğundan bitki gelişimi zayıftır, ekonomik olarak verim ikinci ve sonraki yıllarda yükselir. Bitki 8-10 y1l yaşayabilmektedir ancak ekonomik ömrü 45 yıldır (Bağdat, 2006). Yetiştirilen/doğal olarak yetişen adaçayının verimi türüne ve ekolojik şartlarına göre farklılık göstermektedir. Ülkemizin farklı illerinde Salvia officinalis ile yürütülen bazı çalışmalar ve çalışmalarda incelenen özelliklere ait sonuçlar Tablo 1'de verilmiştir. Çalışmalar farklı dozlarda farklı gübre uygulamalarının (Koç, 2000; Koç, 2006), farklı biçim yüksekliklerinin (Ekren ve ark., 2007), farklı su uygulamalarının (Sönmez, 2015; Yurdcu, 2019), farklı hasat zamanlarının, ontogenetik değişkenliğin (Başyiğit ve Baydar, 2017; Katar ve ark., 2018; Özkeskin, 2019) ve genotip x çevre etkileşimlerinin (Karayel, 2019) sonuçlarını yansıtmaktadır. Çalışmacılar Salvia officinalis'te verim açısından daha çok yeşil herba, drog herba ve drog yaprak verimlerini belirlemişlerdir. Yeşil yaprak verimleri ise az sayıda araştırmacı tarafından bildirilmiştir. İpek (2007), bu türde yeşil yaprak verimini 1787.4-1672.4 kg/da arasında; Şenkal ve ark., (2012) ise ilk y1l $203.61 \mathrm{~kg} / \mathrm{da}$, ikinci y1l $370.42 \mathrm{~kg} / \mathrm{da}$, üçüncü y1l ise $869.02 \mathrm{~kg} / \mathrm{da}$ olarak belirlemişlerdir. Koç (2000) ve Ekren ve ark., (2007) çalışmalarında uçucu yağ analizinde sadece thujon olarak verildiği için, bu yüzde, $\alpha$-thujon yüzdesi olarak yazılmıştır. Yurdcu, (2019) çalışmasını saksı denemesi olarak yapmış ve g olarak belirtilmiştir. 
Tablo 2'de ise ülkemizde doğal olarak yetişen veya yetiştiriciliği yapılmış Salvia fruticosa ile yapılan çalışmalar ve araştırılan özelliklere ait değerler verilmiştir. Çalışmaların çoğunluğu doğal yayılış gösteren türün agronomik ve teknolojik özelliklerine aittir (Schulz ve ark., 2005; Karık, 2013; Karık, 2015; Elmas, 2019). Bayram ve ark., (1999) bu türün ıslahında geliştirilen klonların özelliklerini, Karayel ve Akçura, (2016) farklı lokasyonlarda eşzamanlı yetiştirilen bu türün uçucu yağ bileşimdeki farklılıkları, Katar ve ark., (2019) farklı kurutma sıcaklıklarının uçucu yağ oranı ve bileşenlerine etkisini; Yılmaz, (2019) ve Turhan, (2020) bu türde farklı azot dozu ve hasat zamanlarının agronomik ve teknolojik özelliklerine incelemişlerdir. Salvia fruticosa ile yapılan çalışmalarda da verim açısından en çok incelenen özellikler yeşil herba, drog herba ve drog yaprak verimleri olmuştur. Bu türde yeşil yaprak verimini araştıran Karık (2013), ilk yıl 1371.5-2306.16 $\mathrm{kg} / \mathrm{da}$; ikinci y1l ise 557.9-2530.8 kg/da; Y1lmaz (2019), 422.28-1068.71 kg/da; Turhan (2020), sulu şartlarda yetiştirdiği bu türde ilk yıl 271.26-1191.32 kg/da; ikinci y1l: 322.46-1094.41 kg/da; kuru şartlarda ise ilk y1l 82.34-551.79 kg/da; ikinci y1l ise $538.58-1508.48 \mathrm{~kg} / \mathrm{da}$ olarak belirlemiştir. 
Tablo 1. Türkiye'nin farklı illerinde Salvia officinalis türü ile yürütülen çalışmalara ait sonuçlar

\begin{tabular}{|c|c|c|c|c|c|c|c|c|c|c|}
\hline Çalışmacı & Lokasyon & $\begin{array}{l}\text { Yeşil herba } \\
\text { Verimi } \\
\text { (kg/da) }\end{array}$ & $\begin{array}{c}\text { Drog Herba } \\
\text { Verimi } \\
\text { (kg/da) }\end{array}$ & $\begin{array}{c}\text { Drog Yaprak } \\
\text { verimi } \\
\text { (kg/da) }\end{array}$ & $\begin{array}{l}\text { Ucucu } \\
\text { yăg oranı } \\
(\%)\end{array}$ & $\alpha$-thujon (\%) & $\beta$-thujon (\%) & $\begin{array}{c}\text { 1.8-sineol } \\
(\%)\end{array}$ & $\alpha$-pinene (\%) & $\begin{array}{c}\beta \text {-pinene } \\
(\%)\end{array}$ \\
\hline Koç, 2000 & $\begin{array}{l}\text { Tokat- } \\
\text { Kazova }\end{array}$ & $1569.1-3598.2$ & $361.72-734.85$ & $260.62-447.03$ & $0.88-1.21$ & $19.86-33.12$ & & $9.36-13.94$ & & \\
\hline Koç, 2006 & Ankara & $94.28-103.8\left(\mathrm{~g} / \mathrm{b}^{-1}\right)$ & $25.22-26.88\left(\mathrm{~g} / \mathrm{b}^{-1}\right)$ & & $0.35-0.93$ & & & & & \\
\hline İpek, 2007 & Ankara & $2463.9-2244.3$ & $783.2-739.7$ & $476.9-493.8$ & $1.46-1.60$ & & & & & \\
\hline $\begin{array}{c}\text { Ekren ve } \\
\text { ark., 2007* }\end{array}$ & $\begin{array}{l}\text { İzmir- } \\
\text { Bornova }\end{array}$ & $\begin{array}{l}\text { 1.y: } 328.7-709.1 \\
\text { 2.y: } 2127.6-5004.2\end{array}$ & $\begin{array}{l}\text { 1.y: } 86.5-158.2 \\
\text { 2.y: } 712.7-1494.7\end{array}$ & $\begin{array}{l}\text { 1.y: } 75.5-132.9 \\
\text { 2.y: 527.4-1072.9 }\end{array}$ & $\begin{array}{l}\text { 1.y: } 1.15-1.27 \\
2 . y: 1.40-1.69\end{array}$ & $\begin{array}{l}\text { 1.y: -------- } \\
\text { 2.y: } 12.64-39.29\end{array}$ & & $\begin{array}{l}\text { 1.y: --------- } \\
\text { 2.y: } 3.2-12.35\end{array}$ & $\begin{array}{l}\text { 1.y: }--------- \\
\text { 2.y: } 0.92-3.76\end{array}$ & $\begin{array}{l}\text { 1.y: --------- } \\
\text { 2.y: } 1.05-5.54\end{array}$ \\
\hline $\begin{array}{l}\text { Şenkal ve } \\
\text { ark., } 2012\end{array}$ & $\begin{array}{c}\text { Bolu- } \\
\text { Mudurnu }\end{array}$ & $\begin{array}{l}\text { 1.y: } 445.83 \\
\text { 2.y: } 569.57 \\
\text { 3.y: } 1663.98\end{array}$ & $\begin{array}{l}\text { 1.y: } 147.44 \\
\text { 2.y: } 167.57 \\
\text { 3.y: } 812.42\end{array}$ & $\begin{array}{l}\text { 1.y: } 43.43 \\
\text { 2.y: } 120.52 \\
\text { 3.y: } 339.70\end{array}$ & & & & & & \\
\hline Sönmez, 2015 & $\begin{array}{l}\text { İzmir- } \\
\text { Bornova }\end{array}$ & $\begin{array}{l}\text { 1.y: } 1180.0-1276.6 \\
\text { 2.y: } 2481.4-3300.1 \\
\text { 3.y: } 2193.7-2903.4\end{array}$ & $\begin{array}{l}\text { 1.y: } 434.83-479.91 \\
\text { 2.y: } 719.31-1001.62 \\
\text { 3.y: } 749.42-1017.56\end{array}$ & $\begin{array}{l}\text { 1.y: } 285.32-320.58 \\
\text { 2.y: } 494.9-685.41 \\
\text { 3.y: } 559.89-763.14\end{array}$ & $\begin{array}{l}\text { 1.y: } 0.83-1.0 \\
\text { 2.y: } 1.64-1.79 \\
\text { 3.y: } 1.85-2.01\end{array}$ & $\begin{array}{l}\text { 1.y: } 30.00-39.87 \\
\text { 2.y: } 25.09-34.33 \\
\text { 3.y: } 14.0-36.17\end{array}$ & $\begin{array}{l}\text { 1.y: } 4.14-10.01 \\
\text { 2.y: } 7.20-12.58 \\
\text { 3.y: } 3.86-9.01\end{array}$ & $\begin{array}{l}\text { 1.y: } 3.48-5.31 \\
\text { 2.y: } 3.71-9.48 \\
\text { 3.y: } 0.69-6.4\end{array}$ & $\begin{array}{l}\text { 1.y: --------- } \\
\text { 2.y: } 0.98-1.07 \\
\text { 3.y: } 0.34-1.34\end{array}$ & $\begin{array}{l}\text { 1.y: } 1.02-2.7 \\
\text { 2.y: } 1.01-3.22 \\
\text { 3.y: } 0.7-4.48\end{array}$ \\
\hline $\begin{array}{l}\text { Karakuş ve } \\
\text { ark., } 2017\end{array}$ & Isparta & & & $26.4-638.0$ & $0.60-2.53$ & $0.8-53.2$ & $0.7-54.7$ & $1.0-30.5$ & & \\
\hline $\begin{array}{c}\text { Başyiğit ve } \\
\text { Baydar, 2017 }\end{array}$ & Isparta & $500.0-961.0$ & 223.4- 556.6 & $129.6-367.2$ & $0.83-3.33$ & $15.72-26.26$ & $4.51-27.67$ & $11.93-31.87$ & $1.85-6.63$ & \\
\hline $\begin{array}{c}\text { Katar ve } \\
\text { ark., } 2018\end{array}$ & Eskişehir & & & & $1.0-2.0$ & $23.09-47.24$ & & $4.10-6.30$ & $1.45-4.91$ & $2.16-3.89$ \\
\hline $\begin{array}{c}\text { Tuğlu ve } \\
\text { Baydar, } 2019\end{array}$ & Isparta & $701-1285.7$ & $176.1-368.8$ & $89-202.3$ & $0.9-1.72$ & $1.85-31.01$ & $3.99-17.51$ & $16.48-33.86$ & $3.6-5.4$ & \\
\hline $\begin{array}{c}\text { Özkeskin, } \\
2019\end{array}$ & $\begin{array}{l}\text { Tokat- } \\
\text { Kazova }\end{array}$ & $733.4-1562.2$ & $184.1-533.7$ & $110.7-202.6$ & $0.14-0.19$ & $27.4-33.2$ & $4.6-7.3$ & $9.29-14.74$ & $2.6-8.39$ & $1.18-1.91$ \\
\hline $\begin{array}{c}\text { Karayel, } \\
2019\end{array}$ & Kütahya & & & & $\begin{array}{l}\text { 1.y: } 2.08 \\
\text { 2.y: } 2.23\end{array}$ & $\begin{array}{l}\text { 1.y: } 31.82 \\
\text { 2.y: } 33.46\end{array}$ & $\begin{array}{l}\text { 1.y: } 8.55 \\
\text { 2.y: } 6.68\end{array}$ & $\begin{array}{l}\text { 1.y: } 14.39 \\
\text { 2.y: } 17.32\end{array}$ & $\begin{array}{l}\text { 1.y: } 5.97 \\
\text { 2.y: } 4.36\end{array}$ & $\begin{array}{l}\text { 1.y: } 2.42 \\
\text { 2.y: } 3.20\end{array}$ \\
\hline Yurdcu, 2019 & Çankırı & $25.33-76.0\left(\mathrm{~g} / \mathrm{b}^{-1}\right)$ & $8.00-22.67\left(\mathrm{~g} / \mathrm{b}^{-1}\right)$ & $4.33-12.33\left(\mathrm{~g} / \mathrm{b}^{-1}\right)$ & $1.18-1.96$ & & & & & \\
\hline
\end{tabular}


Elmas, S., Uluslararası Doğu Anadolu Fen Mühendislik ve Tasarım Dergisi / International Journal of Eastern Anatolia Science Engineering and Design (IJEASED) (2021) 3(1):298-332

Tablo 2. Türkiye'nin farklı illerinde Salvia fruticosa türü ile yürütülen çalışmalara ait sonuçlar

\begin{tabular}{|c|c|c|c|c|c|c|c|c|c|c|}
\hline Çalışmacı & Lokasyon & $\begin{array}{l}\text { Yeşil herba } \\
\text { Verimi } \\
\text { (kg/da) }\end{array}$ & $\begin{array}{l}\text { Drog Herba } \\
\text { verimi } \\
\text { (kg/da) }\end{array}$ & $\begin{array}{c}\text { Drog Yaprak } \\
\text { verimi } \\
\text { (kg/da) }\end{array}$ & $\begin{array}{c}\text { Ucucu } \\
\text { yağ oranı } \\
(\%)\end{array}$ & $\begin{array}{c}\text { a-thujon } \\
(\%)\end{array}$ & $\begin{array}{c}\beta \text {-thujon } \\
(\%)\end{array}$ & $\begin{array}{l}\text { 1.8-sineol } \\
(\%)\end{array}$ & $\begin{array}{l}\alpha \text {-pinene } \\
(\%)\end{array}$ & $\begin{array}{c}\beta \text {-pinene } \\
(\%)\end{array}$ \\
\hline $\begin{array}{l}\text { Bayram ve } \\
\text { ark., } 1999\end{array}$ & $\begin{array}{l}\text { İzmir- } \\
\text { Bornova }\end{array}$ & $\begin{array}{l}\text { 1.y: } 1028.8-2055.57 \\
\text { 2.y: } 2870.3-6558.6\end{array}$ & $\begin{array}{l}\text { 1.y: } 475.4-871.0 \\
\text { 2.y: } 666.67-2058.73\end{array}$ & $\begin{array}{l}\text { 1.y: } 332.13-541.6 \\
\text { 2.y: } 585.87-1270.03\end{array}$ & $\begin{array}{l}\text { 1.y: } 3.55-5.28 \\
2 . y: 1.03-5.4\end{array}$ & & & & & \\
\hline $\begin{array}{l}\text { Schulz ve } \\
\text { ark., (2005) }\end{array}$ & $\begin{array}{l}\text { Türkiye- } \\
\text { belirtilmemiş }\end{array}$ & & & & & & & 47.2 & & \\
\hline Karık, 2013 & Tekirdağ & $\begin{array}{l}\text { 1.y: } 2743.47-4533.7 \\
\text { 2.y: } 1140.6-5372.85\end{array}$ & $\begin{array}{l}\text { 1.y: } 862.84-1494.86 \\
\text { 2.y: } 369.82-1460.65\end{array}$ & $\begin{array}{l}\text { 1.y: } 439.86-691.62 \\
\text { 2.y: } 167.74-655.73\end{array}$ & $\begin{array}{l}\text { 1.y: } 3.26-434 \\
2 . y: 2.53-3.88\end{array}$ & $\begin{array}{l}\text { 1.y: } 0.9-2.6 \\
\text { 2.y: } 0.3-2.2\end{array}$ & $\begin{array}{l}\text { 1.y: } 0.6-2.5 \\
\text { 2.y: } 0.4-2.2\end{array}$ & $\begin{array}{l}\text { 1.y: } 24.5-35.8 \\
\text { 2.y: } 23.2-37.3\end{array}$ & $\begin{array}{l}\text { 1.y: } 4.4-5.5 \\
\text { 2.y: } 3.1-6.2\end{array}$ & $\begin{array}{l}\text { 1.y: } 6.1-7.3 \\
2 . y: 3.7-8.7\end{array}$ \\
\hline Karık, 2015 & $\begin{array}{l}\text { Antalya, } \\
\text { Muğla, } \\
\text { Aydın, İzmir }\end{array}$ & $2545.5-4234.4\left(\mathrm{~g} / \mathrm{b}^{-1}\right)$ & $732-1423.2\left(\mathrm{~g} / \mathrm{b}^{-1}\right)$ & $257-587.6\left(\mathrm{~g} / \mathrm{b}^{-1}\right)$ & $2.6-4.3$ & & & $20.7-46.9$ & & $5.3-11.3$ \\
\hline Karayel ve & 1. Kütahya & & & & 1. 1.93 & 1. 1.48 & 1. 2.57 & 1.56 .05 & 1.7 .64 & 1.3 .57 \\
\hline Akçura, & 2. Balıkesir & & & & 2. 2.72 & 2. 5.38 & 2. 3.47 & 2. 33.36 & 2. 7.53 & 2. 4.82 \\
\hline 2016 & 3.Çanakkale & & & & 3. 4.10 & 3. 2.42 & 3. 1.43 & 3. 49.60 & 3. 5.45 & 3. 3.41 \\
\hline $\begin{array}{l}\text { Katar ve } \\
\text { ark., } 2019\end{array}$ & Eskişehir & $1210.7-3298.25$ & & $153.44-348.63$ & $2.20-2.92$ & & & & & \\
\hline Elmas, 2019 & Muğla & $\begin{array}{l}\text { 1.y: } 14.3-133.3 \\
\text { 2.y: } 17.7-95.3\left(\mathrm{~g} / \mathrm{b}^{-1}\right)\end{array}$ & $\begin{array}{l}\text { 1.y: } 8.47-22.2 \\
\text { 2.y: } 7.27-22.7\left(\mathrm{~g} / \mathrm{b}^{-1}\right)\end{array}$ & $\begin{array}{l}\text { 1.y: } 4.37-16.17 \\
\text { 2.y: } 4.07-13.83\left(\mathrm{~g} / \mathrm{b}^{-1}\right)\end{array}$ & $\begin{array}{l}\text { 1.y: } 0.43-3.85 \\
\text { 2.y: } 0.2-4.18\end{array}$ & $\begin{array}{l}\text { 1.y: } 0-4.3 \\
2 . y: 0-5.38\end{array}$ & & $\begin{array}{l}\text { 1.y: } \quad 30.07- \\
67.12 \\
2 . y: 19.16-63.1\end{array}$ & $\begin{array}{l}\text { 1.y: } 2.91-28.56 \\
2 . y: 1.1-32.36\end{array}$ & $\begin{array}{l}\text { 1.y: } 0-14.15 \\
\text { 2.y: } 2.25-21.48\end{array}$ \\
\hline Yılmaz, 2019 & Aydın & $1146.86-2880.7$ & $422.28-1068.71$ & $243.66-516.09$ & $2.17-3.22$ & & & & & \\
\hline $\begin{array}{l}\text { Turhan, } \\
2020 \text { (s. ș.*) }\end{array}$ & Çanakkale & $\begin{array}{l}\text { 1.y: } 395.27-1892.86 \\
\text { 2.y: } 442.86-1275.0\end{array}$ & $\begin{array}{l}\text { 1.y: } 115.3-628.76 \\
\text { 2.y: } 111.73-664.12\end{array}$ & $\begin{array}{l}\text { 1.y: } 351.1-486.05 \\
\text { 2.y: } 318.3-598.39\end{array}$ & $\begin{array}{l}\text { 1.y: } 1.87-2.95 \\
\text { 2.y: } 1.03-3.15\end{array}$ & & & & & \\
\hline $\begin{array}{l}\text { Turhan, } \\
2020 \text { (k. s..**) }\end{array}$ & Çanakkale & $\begin{array}{l}\text { 1.y: } 125.0-551.79 \\
\text { 2.y: } 687.5-2185.71\end{array}$ & $\begin{array}{l}\text { 1.y: } 35.18-204.28 \\
\text { 2.y: } 153.11-802.16\end{array}$ & $\begin{array}{l}\text { 1.y. } 99.90-251.64 \\
\text { 2.y: } 484.1-858.43\end{array}$ & $\begin{array}{l}\text { 1.y: } 1.53-3.05 \\
\text { 2.y: } 1.48-3.08\end{array}$ & & & & & \\
\hline
\end{tabular}


Ülkemizde doğal olarak yetişen veya yetiştiriciliği yapılmış Salvia tomentosa ile yürütülen çalışmalar ise Tablo 3'te verilmiştir. Literatürde bu türün verimiyle ilgili parametreler oldukça azdır, yapılan çalışmalar ise genellikle uçucu yağ oranı ve içeriğini belirlemeye yönelik çalışmalardır. Şenkal ve ark., (2012), Bolu-Mudurnu ekolojik şartlarında yetiştirdikleri Salvia tomentosa' da yeşil herba verimini ilk yıl $132.41 \mathrm{~kg} / \mathrm{da}$, ikinci yıl $426.78 \mathrm{~kg} / \mathrm{da}$ ve üçüncü yıl 1354.9 $\mathrm{kg} / \mathrm{da}$ olarak drog herba verimi ise ilk yıl $43.79 \mathrm{~kg} / \mathrm{da}$, ikinci y1l $145.62 \mathrm{~kg} / \mathrm{da}$ ve üçüncü yıl ise $480.59 \mathrm{~kg} / \mathrm{da}$ olarak belirlemişlerdir. Yeşil yaprak verimlerini sırasıyla $79.45 \mathrm{~kg} / \mathrm{da}, 302.62 \mathrm{~kg} / \mathrm{da}$ ve $461.09 \mathrm{~kg} / \mathrm{da}$; drog yaprak verimlerini ise sirasıyla $21.71 \mathrm{~kg} / \mathrm{da}, 88.63 \mathrm{~kg} / \mathrm{da}$ ve $212.42 \mathrm{~kg} / \mathrm{da}$ olarak belirlemişlerdir. Salvia tomentosa uçucu yağ içeriklerine bakıldığında Şarer’in (1980) çalışması dışında yapılan diğer çalışmalarda analizlerde $\alpha$ ve $\beta$-thujon bileşenlerine rastlanılmamıştır. Şarer, (1980) bu türde $\alpha$-thujon oranını \%3.0 ve $\beta$-thujon oranını ise $\% 0.4$ olarak tespit etmiştir.

Tablo 3. Türkiye'nin farklı illerinde Salvia tomentosa türü ile yürütülen çalışmalara ait sonuçlar.

\begin{tabular}{|c|c|c|c|c|c|c|}
\hline Çalışmacı & Lokasyon & $\begin{array}{l}\text { Ucucu yă } \\
\text { oranı }(\%)\end{array}$ & $\begin{array}{l}\text { 1.8-sineol } \\
(\%)\end{array}$ & $\begin{array}{c}\text { Kafur } \\
(\%)\end{array}$ & $\begin{array}{l}\alpha \text {-pinene } \\
(\%)\end{array}$ & $\underset{(\%)}{\beta \text {-pinene }}$ \\
\hline Şarer, (1980) & Bolu-Abant & 1.30 & 5.6 & 8.6 & 4.0 & 9.7 \\
\hline $\begin{array}{l}\text { Haznedaroğlu ve ark., } \\
\text { (2001) }\end{array}$ & İzmir-Nif Dağı & $0.6-1.3$ & 17 & 0.6 & & 3.7 \\
\hline Başer, (2002) & Türkiye & & & & $6-29$ & $5-33$ \\
\hline Schulz ve ark., (2005) & Türkiye-belirtilmemiş & & 23.0 & 6.0 & 27.9 & \\
\hline Tepe ve ark., (2005) & Osmaniye-Düziçi & & 1.1 & 9.7 & 10.9 & 39.7 \\
\hline $\mathrm{Ay},(2005)$ & Antalya & $0.07-2.1$ & & & $3.1-4.6$ & $4.30-7.10$ \\
\hline Bağcı ve Koçak, (2008) & Elazığ & 0.3 & & & 33.7 & 6.8 \\
\hline Aşkun ve ark., (2010) & Balıkesir-Kazdağı & 1.0 & 7.0 & 14.9 & 25.1 & 1.6 \\
\hline Şenkal ve ark., (2012) & Bolu-Mudurnu & & & & & \\
\hline Ulukanlı ve ark., (2013) & $\begin{array}{l}\text { Osmaniye-Zorkun } \\
\text { Yaylas1 }\end{array}$ & 0.31 & 0.48 & 2.08 & 5.73 & 37.28 \\
\hline Karık ve ark., (2013) & $\begin{array}{l}\text { Yalova, Bursa, } \\
\text { Çanakkale, Balıkesir }\end{array}$ & $0.7-35$ & & $1.5-40.9$ & $1.8-38.9$ & $1.9-35.8$ \\
\hline
\end{tabular}

\subsection{Ekstraksiyon}

Adaçayı yapraklarının genellikle kurutulmuş toprak üstü kısımlarından hidrodistilasyon veya buhar damıtma ile oda sıcaklığında sıvı olan, keskin kokulu, renksiz veya sarı renkli, oranı/verimi türüne göre değişen uçucu yağ elde edilmektedir. Elde edilen uçucu yağ, aromaterapi, parfümeri, kozmetik ve geleneksel halk hekimliğinde kullanılır (Bayram ve Sönmez, 2006). Adaçayı yağı elde etmede geleneksel yöntemlere kıyasla mikrodalga, ultrason destekli ekstraksiyon yöntemleri ve katı-faz mikroekstraksiyonu gibi modern yöntemlerin avantaj ve dezavantajları araştırılmıştır (Koşar ve ark., 2005; Baj ve ark., 2013; Yağcığlu, 2015). Buna göre Anadolu adaçayı ile yürütülen 
çalışmada mikrodalga destekli ekstraksiyon ile uçucu yağ verimlerinin ve 1,8 sineol içeriklerinin normal hidrodistilasyona göre daha yüksek olduğu (Koşar ve ark., 2005), tıbbi adaçayı ile yürütülen çalışmada ise mikrodalga destekli ekstraksiyon yönteminin en verimli yöntem olduğu, bunu ultrason destekli ekstraksiyon ile klasik çözücü ekstraksiyonun takip ettiği bildirilmiştir. Ayrıca mikrodalga destekli ekstraksiyon yönteminin hem daha kısa süreli olduğu hem de yüksek antioksidan kapasitesine sahip olduğu tespit edilmiştir (Yağcığlu, 2015). Tıbbi adaçayı ile yürütülen başka bir çalışmada ise hidrodistilasyon ve katı-faz mikro ekstraksiyonu ile elde edilen uçucu yağda aynı bileşiklerin olduğu, ancak bu bileşenlerin nispi yüzde bileşiminin farklı olduğu belirtilmiş, özellikle ekstraksiyonda sürenin uzaltılması ile uçucu yağ bileşimindeki monoterpenoidlerin azaldığı sesqui ve diterpenoidlerin ise arttığı belirlenmiştir (Baj ve ark., 2013).

Adaçayı yağları halen yaygın olarak hidrodistilasyon veya buhar damıtma gibi geleneksel yöntemlerle elde edilse de modern yöntemler, nispeten daha kısa sürede uçucu yağların üretimi için etkili bir yöntem gibi görünmektedir. Ancak uygulanacak ekstraksiyon yöntemi ve süresi ile birlikte uçucu yağın fenolik bileşenlerinde ve antioksidan özelliklerinde meydana gelecek değişimlerin incelenmesi için daha fazla çalışmaya ihtiyaç vardır.

\subsection{Hastalık ve Zararlıları}

Adaçayı yetiştiriciliğinde yüksek taban suyuna sahip ve geçirimsiz topraklarda bitki kökünün iyi havalanmamasına bağlı olarak toprak kökenli bazı fungal patojenlerin fideliklerde ürün kaybına neden olacak şekilde hastalık oluşturduğu belirtilmiştir (Bayram, 2001; Karık, 2013). Literatürde adaçayında mildiyö, çökerten, kök çürüklüğü, antraknoz, külleme, beyaz çürüklük hastalıklarına neden olan bir dizi fungusun (Rhizoctonia solani, Colletotrichum dematium, Ascochyta sclarea, Erysiphe cichoracearum, Peronospora lamii, Sclerotinia sclerotiorum, Phytophthora cryptogea, Phomopsis sclarea, Phodosphaera inequalis, Erysiphae polygoni, Sclerotinia sclerotiorum) adaçayında ekonomik kayıplara neden olduğu bildirilmektedir. Fusarium türlerinin (özellikle Fusarium oxysporum, Fusarium solani, Fusarium moniliforme, Fusarium culmorum) adaçayında kök çürüklügü ve solgunluk oluşturduğu, Alternaria alternata türlerinin yapraklarda nekrotik semptomlara ve Ascochyta sclarea türlerinin antraknoza neden olduğu bildirilmektedir (Çakır ve ark., 2016; Zimowska, 2008). 
Ülkemizde adaçayı yetiştiriciliğinde karşılaşılan hastalıklar ve tedavileri ilgili çalışmalar nadirdir. Salvia fruticosa' da hem verim ve kalitenin artırılması hem de hastalıklardan kaynaklanan verim kayıplarının azaltılabilmesi için Trichoderma harzianum Rifai KRL-AG2 biyolojik ajanının toprak kaynaklı hastalıkları (Fusarium spp.) baskılamada ümitvar bir sonuç verdiği ifade edilmiştir (Polat ve Tinmaz, 2014).

Adaçayı üretimini sınırlayan temel faktörlerden biri de bu bitki ile beslenen zararlılardır. Bornova ve Menemen ekolojik koşullarında yetiştirilen Salvia officinalis'te Eucarazzia elegans'ın (yaprakbiti) ilkbahar döneminde \%9.5 zarar oranı ile bir önceki yıldan kalan yaşlı yapraklar üzerinde beslendiği, yaz başında \%1.1 zarar oranı ile genç yapraklara ve çiçeklere göç ettiği saptanmıştır. Yaprakbitlerinin, adaçayında 8-10 haftadan fazla beslenmesinin $\% 50$ 'den fazla ürün kaybına neden olduğu belirlenmiştir (Zarkani ve ark., 2017). Bir başka çalışmada Salvia officinalis üzerinde 31 farklı familyaya ait 51 böcek türü olduğu, ayrıca 23 predatör ve 6 parazitoitin bu bitkide doğal düşman türü olduğu belirlenmiştir (Hazairin, 2018). Her iki çalışmada da Salvia officinalis'te yaprakbiti zararının uçucu yağ miktarı üzerinde önemli bir etkisinin olmadığı ancak uçucu yağ bileşenlerinin bazılarında büyük ölçüde değişime uğrattığı bildirilmiştir (Zarkani ve ark., 2017; Hazairin, 2018).

\subsection{Kalite ve Muhafaza}

İç ve dış pazarda geniş kullanım alanına sahip olan tıbbi ve aromatik bitkilerde kalite söz konusu olduğunda bilinmesi gereken bazı hususlar vardır. Bunlar arasında bitkinin botanik ismi, menşei ülkesi veya bölgesi, biçim zamanı, duyu testleri, yabancı madde testleri, makroskopik testler ile kimyasal ve kromotografik analizler bulunmaktadır. Ayrıca kemirgen ve böcek bulaşıklığı, nem içeriği, kül oranı, pestisit, radyoaktivite ve mikroskobik kirlenmeye dair testler de yapılmalıdır. Bitkilerin mikrobiyolojik kalitesini yetiştiği/yetiştirildiği bölge, kurutma koşulları, işleme sonrası çevresel, iklimsel ve antropojenik koşullar ile taşıma, depolanma, paketlenme koşulları belirler. Bitkilerdeki mikroskopik kirlenmeyi tespit etmek, bitki içeriğindeki patojen organizmaların, bakterilerin, mikotoksinlerin ve mikrobik toksinlerin oluşturduğu mikroorganizma yükünü belirlemek açısından önemlidir. Bu nedenle çeşitli kullanım alanlarına sahip bitkisel ürünlerde mikroorganizma içeriği, iyi ve hijyenik üretimin, başka bir deyişle kalite ve güvenliğin bir belirteci olarak kabul edilebilir (Bayram ve ark., 2010; Faydaoğlu ve Sürücüoğlu, 2011). Adaçayının mikrobiyolojik kalitesinin belirlendiği bir çalışmada açık, 
yarı açık ve kapalı ambalajlarda satışa sunulan 12 farklı adaçayı örneğinde, \%83.33 toplam mezofilik aerobik bakteri, \%75 Enterobacteriaceae, \%75 koliform, \%16.6 Staphylococcus \& Micrococcus spp., \%100 küf-maya ve \%16.6 sülfit indirgeyen anaerob bakteri tespit edilmiştir. Araştırmacılar perakende satışa sunulan adaçayının mikrobiyolojik kalitesinin yetersiz olduğunu ve bunların Escherichia coli ve Salmonella spp. gibi patojenlerle kontamine olabileceğini belirtmişlerdir (Vural ve ark., 2020).

Tıbbi ve aromatik bitkilerin kullanımında birtakım kontaminasyonlar dışında tehdit oluşturabilecek diğer bir sorun pestisidlerin, endüstri ve evsel atıkların oluşturduğu ağır metal kirliliğidir. Bitkiler, suda ve toprakta biriken ağır metalleri kökler vasıtasıyla bünyelerine almasıyla, yapay veya doğal gübrelerin yapısında bulunan bileşiklerin yağmur veya sulama ile toprağa karışması sonucu veya antropojenik olan ağır metal kirliliğine maruz kalabilir. Bu nedenle yaygın kullanıma sahip bitkilerin ağır metaller bakımından incelenmesi, bunların güvenilir sınırlar dahilinde olup olmadıklarının belirlenmesi olası toksik etkilerin önüne geçebilir (Alkaya ve ark., 2015). Bu konuyla ilgili yapılan çalışmalarda, aktarlarda satılan adaçayı örneklerinde (Salvia fruticosa L., Salvia officinalis L. ve Sideritis condensata Boiss. \& Heldr.) farkl1 miktarlarda bor, kalsiyum, magnezyum, potasyum ve sodyum mineral besin elementleri ile bakır, çinko, demir, kadmiyum, kurşun, krom, mangan, nikel ağır metalleri tespit edilmiştir. Araştırmacılar, bu ağır metallerin sağlık açısından toksik etki oluşturmayacak miktarlarda, Gıda ve Kontrol Genel Müdürlüğü yönetmeliğinin belirlediği sınırlar içinde olduklarını belirtmişlerdir (Turan, 2014; Alkaya ve ark., 2015).

Alternatif tıpta pek çok hastalığın tedavisinde yararlanılan tıbbi ve aromatik bitkilerin kullanılmasında analizleri yapılmış, içeriği belli, kaliteli olan türler tercih edilmelidir. ISO 11165 (1995) standartlarına göre adaçayı yapraklarında en az \%1.5 uçucu yağ ve ISO 9909 (1997) standartlarına göre, tıbbi adaçayı uçucu yağında $\alpha$-thujon \%18.0-43.0, ( $\alpha / \beta$-thujonlar ( $>\% 50)$, $\beta$-thujon \%3.0-8.5, kafur $\% 4.5-24.5,1,8$-sineol \%5.5-13.0, kamfen \%1.5-7.0, limonen \%0.5-3.0, $\alpha$-humulen $<\% 12.0, \alpha$-pinen $\% 1.0-6.5$, bornil asetat $<\% 2.5$ ve linalol+linalil asetat $<\% 1.0$ değerlerinde olması gerekmektedir (Karakuş ve ark., 2017). Ancak adaçayı içindeki minimum polifenol içeriği için standart resmi bir kriter yoktur. $\mathrm{Bu}$ nedenle hem ülkemizdeki hem de uluslararası veri tabanlarında adaçayının da içinde bulunduğu birçok tıbbi ve aromatik bitki için belli standartlara dayandırılmış resmi kriterlerin olması, standart ticaret sınıflaması kodlarının olması ve bunların hukuki düzenlemeler ve denetlemelerle desteklenmesi gereklidir (Acıbuca ve Budak, 2018). 


\section{Destekler}

Tarım ve Orman Bakanlığı tarafından 2015 yılından itibaren, dünya piyasalarının ihtiyaç duyduğu nitelik ve miktarda tıbbi ve aromatik bitki yetiştiriciliği için çiftçilere doğrudan destekleme verilmektedir. 05.10.2020 tarih ve 31295 sayılı Resmi Gazetede yayımlanan '2020 Y1lında Yapılacak Tarımsal Desteklemelere İlişkin Karar'da tıbbi ve aromatik bitki yetiştiriciliği için bitkisel üretim yapan küçük aile işletmesi desteği dekar başına 100 TL; iyi tarım uygulamaları kapsamında bireysel sertifikasyona dekar başına $100 \mathrm{TL}$, grup sertifikasına dekar başına $50 \mathrm{TL}$, mazot desteği $15 \mathrm{TL} /$ da, gübre desteği $4 \mathrm{TL} /$ da, katı organik-organomineral gübre desteği $10 \mathrm{TL} / \mathrm{da}$ olarak, organik tarım kapsamında ise üçüncü kategoride yer alan adaçayı için $30 \mathrm{TL} / \mathrm{da}$, ayrıca toprak analizi desteği (TL/numune) ise $40 \mathrm{TL}$ destek verilmektedir.

\section{Ticari Önemi}

Türkiye, üç farklı floristik bölgenin kesişim noktasında bulunması, farklı topografik ve iklimsel özelliklere sahip olması sayesinde tıbbi ve aromatik bitkiler bakımından oldukça zengin bir ülkedir. Gelişmiş ve gelişmekte olan çok sayıda ülkeye eczacılık, gıda ve katkı maddeleri, kozmetik ve parfümeri gibi pek çok alanda kullanılmak üzere ihraç edilen tıbbi ve aromatik bitkilerin önemli bir kısmı ülkemiz florasından karşılanmaktadır (Bayram ve ark., 2010). Bu bitkiler arasında kekik, defne, kimyon, haşhaş, anason, rezene, mahlep, biberiye ve adaçayı bulunmaktadır. Son yıllarda yetiştiriciliği yapılan adaçayı, üreticiler açısından getirisi yüksek karlı bir tarım ürünü olarak dikkat çekmektedir. Adaçayının drog herbası ve uçucu yağına, kullanım alanları itibariyle, dünyadaki talep giderek artmakta, bu da bitkinin tarımını önemli hale getirmektedir. Ülkemizde adaçayı ihracatının büyük bir kısmını doğadan yoğun bir şekilde toplanan Salvia fruticosa ve Salvia tomentosa türleri oluşturmakta olup, Salvia cryptantha, Salvia multicaulis, Salvia sclarea'nın da ticaretinin yapıldığ 1 belirtilmiştir (İpek ve Gürbüz, 2010; Tıbbi Adaçayı Yaygınlaştırma Raporu, 2018). Ayrıca Salvia cinsi dışında Sideritis L. (Sideritis congesta, Sideritis caesarea, Sideritis scardica, Sideritis pisidica, Sideritis arguta, Sideritis leptoclada, Sideritis condensata, Sideritis trojana, Sideritis athoa, Sideritis dichotoma, Sideritis perfoliata ve Sideritis libanotica) ve Stachys L. (Stachys rupestris, Stachys obliqua) cinslerine ait bazı türler de adaçayı olarak kullanılmaktadır (Duru ve ark., 1994; Yılmaz ve Güvenç, 2007). Ancak doğadan toplamada standart ürün eldesi pek mümkün 
Elmas, S., Uluslararası Doğu Anadolu Fen Mühendislik ve Tasartm Dergisi / International Journal of Eastern Anatolia Science Engineering and Design (IJEASED)

(2021) 3(1):298-332

değildir ve artan toplama baskısı adaçayı popülasyonlarına ciddi zarar vermekte, biyolojik çeşitliliği riske atmaktadır (İpek ve Gürbüz, 2010; Karık, 2013). Bu nedenle son y1llarda ülkemizin farklı illerinde, tüketici ve sanayicinin artan taleplerini karşılamak amacıyla standartlara uygun olarak belirli ölçüde adaçayı yetiştiriciliği yapılmaktadır. Tablo 4'te ülkemizde 2012-2019 yılları arasında illere göre ekilen alan (da), verim (kg/da) ve üretim miktarları (ton) verilmiştir. Bu yıllar arasında kültürü yapılan adaçayında toplam ekilen alan (da) açısından Denizli, Kütahya, Antalya ve Tekirdağ illerinin; toplam verim ( $\mathrm{kg} / \mathrm{da})$ açısından Karaman, Antalya, Muğla ve Kütahya illerinin, toplam üretim miktarı (ton) açısından ise Denizli, Antalya ve Kütahya illerinin diğerlerine göre daha yüksek değerlere ulaştığı söylenebilir (TÜİK, 2021). Ancak bu verilerde yetiştiriciliği yapılan ürün sadece 'adaçayı' olarak ifade edilmiş, hangi türe ait olduğu belirtilmemiştir.

Tablo 4. 2012-2019 yılları arası adaçayı yetiştiriciliği yapılan illere ait ekilen alan, verim ve üretim miktarı verileri

İller Adana Antalya Denizli Düzce Eskişehir Karaman Kayseri Kütahya Manisa Muğla Tekirdağ Ușak İzmir

\begin{tabular}{|c|c|c|c|c|c|c|c|c|c|c|c|c|c|c|}
\hline $\begin{array}{c}\text { Ekilen } \\
\text { Alan } \\
\text { (da) }\end{array}$ & 2012 & & & & & & 54 & & & & & & & \\
\hline & 2013 & & & & & & 30 & & & & & & & \\
\hline & 2014 & & & & & & 30 & & & & 100 & & & \\
\hline & 2015 & & & 50 & & & 31 & & 355 & & 100 & & & \\
\hline & 2016 & & 5 & 2735 & & 5 & 35 & & 641 & & 114 & 140 & & 6 \\
\hline & 2017 & 85 & 5 & 2781 & & 5 & 30 & 3 & 645 & 185 & 118 & 240 & 20 & 6 \\
\hline & 2018 & 85 & 5 & 2611 & & 5 & 27 & 3 & 491 & 185 & 203 & 310 & 20 & 6 \\
\hline & 2019 & 10 & 2556 & 1637 & 45 & 5 & 23 & 3 & 541 & 185 & 209 & 362 & 20 & 6 \\
\hline & Toplam & 180 & 2571 & 9814 & 45 & 20 & 260 & 9 & 2673 & 555 & 844 & 1052 & 60 & 24 \\
\hline $\begin{array}{l}\text { Verim } \\
(\mathbf{k g} / \mathbf{d a})\end{array}$ & 2012 & & & & & & 130 & & & & & & & \\
\hline & 2013 & & & & & & 133 & & & & & & & \\
\hline & 2014 & & & & & & 133 & & & & 150 & & & \\
\hline & 2015 & & & 160 & & & 129 & & 149 & & 150 & & & \\
\hline & 2016 & & 200 & 101 & & 200 & 143 & & 152 & & 149 & 100 & & 167 \\
\hline & 2017 & 153 & 200 & 98 & & 200 & 133 & 0 & 281 & 151 & 144 & 150 & 100 & 167 \\
\hline & 2018 & 153 & 200 & 94 & & 200 & 148 & 0 & 126 & 151 & 138 & 135 & 100 & 167 \\
\hline & 2019 & 400 & 345 & 96 & 111 & 200 & 130 & 0 & 129 & 151 & 139 & 138 & 100 & 167 \\
\hline & Toplam & 706 & 945 & 549 & 111 & 800 & 1079 & 0 & 837 & 453 & 870 & 523 & 300 & 668 \\
\hline Üretim & & & & & & & & & & & & & & \\
\hline $\begin{array}{c}\text { Miktarı } \\
\text { (Ton) }\end{array}$ & 2012 & & & & & & 7 & & & & & & & \\
\hline & 2013 & & & & & & 4 & & & & & & & \\
\hline & 2014 & & & & & & 4 & & & & 15 & & & \\
\hline & 2015 & & & 8 & & & 4 & & 53 & & 15 & & & \\
\hline & 2016 & & 1 & 275 & & 1 & 5 & & 97 & & 17 & 14 & & 1 \\
\hline & 2017 & 13 & 1 & 273 & & 1 & 4 & 0 & 181 & 28 & 17 & 36 & 2 & 1 \\
\hline & 2018 & 13 & 1 & 246 & & 1 & 4 & 0 & 62 & 28 & 28 & 42 & 2 & 1 \\
\hline & 2019 & 4 & 883 & 157 & 5 & 1 & 3 & 0 & 70 & 28 & 29 & 50 & 2 & 1 \\
\hline & Toplam & 30 & 886 & 959 & 5 & 4 & 35 & 0 & 463 & 84 & 121 & 142 & 6 & 4 \\
\hline
\end{tabular}


Tablo 5'te ülkemizde doğal olarak yetişen ve tarımı yapılan adaçayının yıllara göre ihracat miktarı ve değerleri verilmiştir. 2010-2020 yılları arasında, ABD, Almanya, Fransa, İtalya, İspanya'nın da bulunduğu toplam 65 ülkeye adaçayı ihracatı yapılmıştır. Ülkemizin 2016-2020 yılları arasındaki ortalama yıllık adaçayı ihracatı yaklaşık 2100 ton civarındadır. 2020 yılında Salvia officinalis ihracatında $1610 \mathrm{~kg}$ ile Almanya ilk sırada yer alırken, Salvia officinalis dışı adaçayı ihracatında 1255 ton ile Ege Serbest Bölgesi ilk sırada yer almış, toplam 2.176.139 kg ile 8.155.50 dolar döviz girdisi elde edilmiştir. Tablo 5 incelendiğinde doğadan toplanan adaçayının yetiştirilen adaçayının yaklaşık 180 katı olduğu göze çarpmaktadır. Ancak doğadan toplanan adaçayına ait tam kayıtlar bulunmamakta, dolayısıyla iç tüketimle ne kadar tüketildiği bilinmemektedir. Bu nedenle doğadan toplanan adaçayının, tarımı yapılandan çok daha fazla olduğu açıktır.

Tablo 5. 2016-2020 yıllarına ait adaçayı ihracat (\$, kg) değerleri

\begin{tabular}{|c|c|c|c|c|c|c|c|c|c|c|}
\hline \multirow{2}{*}{$\begin{array}{c}\text { Yıllar } \\
\text { Tür }\end{array}$} & \multicolumn{2}{|c|}{2016} & \multicolumn{2}{|c|}{2017} & \multicolumn{2}{|c|}{2018} & \multicolumn{2}{|c|}{2019} & \multicolumn{2}{|c|}{2020} \\
\hline & $\begin{array}{l}\text { İhracat } \\
\text { Değerleri } \\
\text { (\$) }\end{array}$ & $\begin{array}{l}\text { İhracat } \\
\text { Miktarları } \\
(\mathrm{kg})\end{array}$ & $\begin{array}{l}\text { İhracat } \\
\text { Değerleri } \\
\text { (\$) }\end{array}$ & $\begin{array}{l}\text { İhracat } \\
\text { Miktarları } \\
(\mathrm{kg})\end{array}$ & $\begin{array}{l}\text { İhracat } \\
\text { Değerleri } \\
(\$)\end{array}$ & $\begin{array}{l}\text { İhracat } \\
\text { Miktarları } \\
(\mathrm{kg})\end{array}$ & $\begin{array}{l}\text { İhracat } \\
\text { Değerleri } \\
\text { (\$) }\end{array}$ & $\begin{array}{l}\text { İhracat } \\
\text { Miktarları } \\
\text { (kg) }\end{array}$ & $\begin{array}{l}\text { İhracat } \\
\text { Değerleri } \\
\text { (\$) }\end{array}$ & $\begin{array}{l}\text { İhracat } \\
\text { Miktarları } \\
(\mathrm{kg})\end{array}$ \\
\hline Salvia officinalis & 569.19 & 73.107 & 327.987 & 63.508 & 214.091 & 28.329 & 119.559 & 6.936 & 210.871 & 12.008 \\
\hline $\begin{array}{l}\text { S. officinalis } \\
\text { harici }\end{array}$ & 7.081.905 & 1.997 .905 & 6.729 .430 & 1.843 .946 & 6.967 .544 & 1.932.902 & 8.561.004 & 2.310 .413 & 7.944.632 & 2.164.131 \\
\hline Yıl Toplamı & 7.651 .095 & 2.071 .012 & 7.057.417 & 1.907 .454 & 7.181.635 & 1.961.231 & 8.680 .563 & 2.317.349 & 8.155 .503 & 2.176.139* \\
\hline
\end{tabular}

Ülkemiz adaçayının dünya çapında önemli bir ihracatçısı olmakla beraber aynı zamanda önemli bir ithalatçısıdır. Özellikle Avrupa ülkelerinin artan adaçayı talebini karşılamak amacıyla yeniden ihraç edilmek üzere Arnavutluk, Lübnan gibi ülkelerden adaçayı ithalatı yapılmaktadır (Keykubat, 2016). Tablo 6 incelendiğinde sadece 2019 yılında yapılan Salvia officinalis ’in $106 \mathrm{~kg}$ ithalatı yapılırken, 2020 yılında ise Salvia officinalis dışı $1.171 .152 \mathrm{~kg}$ adaçayı ithalatı yapılmıştır.

Tablo 6. 2016-2020 yıllarına ait adaçayı ithalat $(\$, \mathrm{~kg})$ değerleri

\begin{tabular}{|c|c|c|c|c|c|c|c|c|c|c|}
\hline Yillar & \multicolumn{2}{|c|}{2016} & \multicolumn{2}{|c|}{2017} & \multicolumn{2}{|c|}{2018} & \multicolumn{2}{|c|}{2019} & \multicolumn{2}{|c|}{2020} \\
\hline Tür & $\begin{array}{c}\text { İthalat } \\
\text { Değerleri } \\
\text { (\$) }\end{array}$ & $\begin{array}{l}\text { İthalat } \\
\text { Miktarları } \\
(\mathrm{kg})\end{array}$ & $\begin{array}{l}\text { İthalat } \\
\text { Değerleri } \\
\text { (\$) }\end{array}$ & $\begin{array}{l}\text { İthalat } \\
\text { Miktarları } \\
(\mathrm{kg})\end{array}$ & $\begin{array}{l}\text { İthalat } \\
\text { Değerleri } \\
(\$)\end{array}$ & $\begin{array}{c}\text { İthalat } \\
\text { Miktarları } \\
(\mathrm{kg})\end{array}$ & $\begin{array}{l}\text { İthalat } \\
\text { Değerleri } \\
\text { (\$) }\end{array}$ & $\begin{array}{c}\text { İthalat } \\
\text { Miktarları } \\
(\mathrm{kg})\end{array}$ & $\begin{array}{l}\text { İthalat } \\
\text { Değerleri } \\
\text { (\$) }\end{array}$ & $\begin{array}{l}\text { İthalat } \\
\text { Miktarları } \\
(\mathrm{kg})\end{array}$ \\
\hline Salvia officinalis & $\mathbf{0}$ & $\mathbf{0}$ & $\mathbf{0}$ & $\mathbf{0}$ & 0 & $\mathbf{0}$ & 408 & 106 & 0* & 0* \\
\hline $\begin{array}{c}\text { S. officinalis } \\
\text { harici }\end{array}$ & 3.008.811 & 1.446.138 & 1.823 .828 & 942.41 & 1.620 .684 & 743.98 & 2.645.909 & 1.073 .040 & 3.103.944 & 1.171.152 \\
\hline Yıl Toplamı & 3.008.811 & 1.446 .138 & 1.823.828 & 942.41 & 1.620 .684 & 743.98 & 2.646.317 & 1.073 .146 & 3.103.944 & 1.171.152 \\
\hline
\end{tabular}


Elmas, S., Uluslararası Doğu Anadolu Fen Mühendislik ve Tasartm Dergisi / International Journal of Eastern Anatolia Science Engineering and Design (IJEASED)

(2021) 3(1):298-332

Türkiye'nin önemli dış satım ürünlerinden biri olan adaçayının, hem herba olarak hem de uçucu yağ olarak ayrı ayrı gümrük tarife pozisyonu altında ticareti yapılmaktadır. Tablo 7'de 20162020 yılları arasında adaçayı ihracatının yapıldığı ülkelere ait miktar ve tutarlar sunulmuştur. Buna göre 2020 yılında $20.733 \mathrm{~kg}$ ile İspanya ilk sırada yer almış, toplam $27.396 \mathrm{~kg}$ terpeni alınmamış adaçayı yağı karşılığı 173.504 dolar döviz girdisi elde edilmiştir. 2019 ve 2020 yıllarında adaçayı yağı ihracatının ivme kazandığı görülmekte olup, son beş yılın ortalama adaçayı yağı ihracatı yaklaşık 11.3 ton civarındadır. 2020 yılı ihracatında bir önceki yıla oranla yaklaşık \%48 oranında artış görülmektedir.

Tablo 7. 2016-2020 yıllarına ait adaçayı yağı ihracat (\$, kg) değerleri

\begin{tabular}{lcccccccccc}
\multicolumn{1}{c}{ Ülkeler/Yıllar } & \multicolumn{2}{c}{2016} & \multicolumn{2}{c}{2017} & \multicolumn{2}{c}{2018} & \multicolumn{2}{c}{2019} & \multicolumn{2}{c}{2020} \\
& $\begin{array}{c}\text { Dolar } \\
(\$)\end{array}$ & $\mathrm{kg}$ & $\begin{array}{c}\text { Dolar } \\
(\$)\end{array}$ & $\mathrm{Kg}$ & $\begin{array}{c}\text { Dolar } \\
(\$)\end{array}$ & $\mathrm{kg}$ & $\begin{array}{c}\text { Dolar } \\
(\$)\end{array}$ & $\mathrm{kg}$ & $\begin{array}{c}\text { Dolar } \\
(\$)\end{array}$ & $\mathrm{kg}$ \\
ABD & 93.547 & 450 & 0 & 0 & 0 & 0 & 0 & 0 & 154.832 & 800 \\
Almanya & 0 & 0 & 114 & 4 & 0 & 0 & 0 & 0 & 558 & 760 \\
Azerbaycan & 130 & 11 & 0 & 0 & 0 & 0 & 0 & 0 & 0 & 0 \\
BAE & 0 & 0 & 2796 & 100 & 0 & 0 & 0 & 0 & 0 & 0 \\
Belarus & 0 & 0 & 110 & 313 & 0 & 0 & 0 & 0 & 0 & 0 \\
Bulgaristan & 0 & 0 & 0 & 0 & 5559 & 9473 & 15.555 & 18.429 & 1.447 & 3.148 \\
Hong Kong & 0 & 0 & 0 & 0 & 442 & 3 & 0 & 0 & 0 & 0 \\
İspanya & 0 & 0 & 0 & 0 & 0 & 0 & 0 & 0 & 15.231 & 20.733 \\
Kanada & 0 & 0 & 0 & 0 & 0 & 0 & 0 & 0 & 108 & 147 \\
Mersin S.B. & 1.587 & 11 & 0 & 0 & 0 & 0 & 0 & 0 & 0 & 0 \\
Nijerya & 0 & 0 & 0 & 0 & 2065 & 55 & 0 & 0 & 0 & 0 \\
SuudiArabistan & 0 & 0 & 0 & 0 & 600 & 5 & 0 & 0 & 0 & 0 \\
Tayvan & 0 & 0 & 0 & 0 & 117 & 3 & 0 & 0 & 0 & 0 \\
Yunanistan & 0 & 0 & 0 & 0 & 0 & 0 & 0 & 0 & 1.328 & 1.808 \\
Toplam & $\mathbf{9 5 . 2 6 4}$ & $\mathbf{4 7 2}$ & $\mathbf{3 . 0 2}$ & $\mathbf{4 1 7}$ & $\mathbf{8 . 7 8 3}$ & $\mathbf{9 . 5 3 9}$ & $\mathbf{1 5 . 5 5 5}$ & $\mathbf{1 8 . 4 2 9}$ & $\mathbf{1 7 3 . 5 0 4}$ & $\mathbf{2 7 . 3 9 6}$
\end{tabular}

Adaçayı yağının 2016-2020 yılları arasındaki ithalat verileri Tablo 8'de sunulmuştur. Buna göre son beş yılın ortalama adaçayı yağı ithalatı ise yaklaşık 645 kg'dır. Adaçayı yağında ortalama ihracat değeri ithalat değerinin iki katına yakındır. 2020 yılında ithalatı bir önceki yıla göre yaklaşık \%58 artış göstermiştir (TÜİK, 2021). 
Tablo 8. 2016-2019 yıllarına ait adaçayı yağı ithalat $(\$, \mathrm{~kg})$ değerleri

\begin{tabular}{|c|c|c|c|c|c|c|c|c|c|c|}
\hline \multirow[t]{2}{*}{ Ülkeler/Yıllar } & \multicolumn{2}{|c|}{2016} & \multicolumn{2}{|c|}{2017} & \multicolumn{2}{|c|}{2018} & \multicolumn{2}{|c|}{2019} & \multicolumn{2}{|c|}{2020} \\
\hline & $\begin{array}{c}\text { Dolar } \\
(\$)\end{array}$ & $\mathrm{kg}$ & $\begin{array}{c}\text { Dolar } \\
(\$)\end{array}$ & $\mathrm{kg}$ & $\begin{array}{c}\text { Dolar } \\
(\$)\end{array}$ & $\mathrm{Kg}$ & $\begin{array}{c}\text { Dolar } \\
(\$)\end{array}$ & $\mathrm{Kg}$ & $\begin{array}{c}\text { Dolar } \\
(\$)\end{array}$ & $\mathrm{kg}$ \\
\hline ABD & 0 & 0 & 0 & 0 & 0 & 0 & 117 & 1 & 103 & 1 \\
\hline Almanya & 0 & 0 & 0 & 0 & 5.9 & 50 & 0 & 0 & 0 & 0 \\
\hline Arnavutluk & 0 & 0 & 135 & 1 & 0 & 0 & 3.124 & 50 & 0 & 0 \\
\hline Avustralya & 0 & 0 & 0 & 0 & 600 & 5 & 0 & 0 & 0 & 0 \\
\hline Avusturya & 0 & 0 & 0 & 0 & 41.197 & 402 & 11.039 & 95 & 1.391 & 20 \\
\hline Bosna Hersek & 0 & 0 & 0 & 0 & 0 & 0 & 122 & 1 & 0 & 0 \\
\hline Çin & 126 & 1 & 0 & 0 & 6.991 & 25 & 10.174 & 50 & 4.927 & 25 \\
\hline Fransa & 22.187 & 82 & 56.482 & 227 & 0 & 0 & 1.28 & 3 & 26.807 & 132 \\
\hline Hindistan & 0 & 0 & 0 & 0 & 4.368 & 105 & 373 & 5 & 7.338 & 202 \\
\hline İngiltere & 0 & 0 & 0 & 0 & 0 & 0 & 5200 & 40 & 0 & 0 \\
\hline İspanya & 27.02 & 105 & 67.157 & 261 & 27.29 & 393 & 15.511 & 351 & 11.886 & 251 \\
\hline İtalya & 1.928 & 25 & 0 & 0 & 0 & 0 & 0 & 0 & 0 & 0 \\
\hline Macaristan & 0 & 0 & 0 & 0 & 0 & 0 & 0 & 0 & 3.263 & 50 \\
\hline Paraguay & 0 & 0 & 0 & 0 & 0 & 0 & 0 & 0 & 16.159 & 200 \\
\hline Rusya & 12.914 & 50 & 12.287 & 50 & 0 & 0 & 783 & 5 & 643 & 5 \\
\hline Toplam & 64.175 & 263 & 136.061 & 539 & 86.346 & 980 & 42.523 & 561 & 72.517 & 886 \\
\hline
\end{tabular}

\section{Sonuçlar ve Öneriler}

Türkiye'nin üç önemli floristik bölgenin kesişim noktasında bulunması, farklı ekolojik koşullara, iklimsel özelliklere ve geniş yüzölçümüne sahip olması, florada biyolojik çeşitlilik açısından zenginlik sağlamıştır (Bayram ve ark., 2010). Yakın Doğu ve Akdeniz gen merkezlerinin kesiştiği noktada yer alan ülkemiz, doğada yetişen ve kültürü yapılan tıbbi ve aromatik bitkiler açısından önemli bir ticari potansiyele sahiptir (Altındal ve Akgün, 2015). Bu tıbbi ve aromatik bitkiler içerisinde, yıllara göre farklı miktarlarda adaçayı bitkisi ve yağı iki ayrı gümrük tarifesi altında farklı ülkelere ihraç edilmektedir. Son yıllarda ülkemizin birçok il ve ilçesinde adaçayı yetiştiriciliği yapılmaktadır ancak veriler incelendiğinde doğadan toplanan adaçayı miktarının üretimi yapılandan çok daha fazla olduğu görülmektedir. Türkiye'nin sahip olduğu tarımsal potansiyel göz önüne alınırsa adaçayı üretimi ve ticaretinin henüz istenilen seviyelerde yapılmadığı söylenebilir. Dış ticaret verilerinde, ihracatı yapılan adaçayının aynı zamanda ithalatının da yapıldığı görülmektedir. Bu durum sektördeki aracı ve firmaların tercihleri olabilmekle beraber, ülkemizde adaçayının işlenmesi, standardizasyon, tasnifleme ve satışa hazır hale getirilmesi gibi faaliyetlerin henüz istenen düzeyde olmaması nedeniyle gerçekleşmektedir (Bağdat, 2006). 
İç ve dış ticaretimizde önemli bir yeri olan adaçayı, TÜiK veri sisteminde 'Salvia officinalis; küçük paketler içerisinde bitkisel çay olarak kullanılanlar ve Salvia officinalis; küçük paketler içerisinde bitkisel çay olarak kullanılanlar hariç’ olmak üzere iki ayrı fasılda yer almaktadır. Ancak 'hariç' olarak belirtilen türlerin isimleri, ürün grupları, toplandığı bölge/lokasyon ve miktarları açık ve net olarak yer almamaktadır. Tüm bunlara ek olarak adaçayının iç tüketimiyle ilgili istatistiki verilerin kaydı bulunmamaktadır, bu nedenle doğadan toplanan veya tarımı yapılan adaçayının iç tüketimle ne kadar tüketildiği bilinmemektir. Özellikle doğadan toplama sonucu elde edilen adaçayında toplamanın yapıldığı alanın mutlaka belirtilmesi gereklidir. Toplama alanlarını takip etmek, şiddetli ve kontrolsüz toplamanın önüne geçilmesinde, habitat kaybı, habitat parçalanması, yabancı ve istilacı türler gibi biyoçeşitliliği etkileyen her türlü faktörün önlenmesinde ve floradaki hasat baskının azaltılmasına katkıda bulunacaktır. Ayrıca Salvia cinsine veya diğer cinslere ait adaçayı olarak toplanan türlerde meydana gelebilecek olası bir genetik erozyonun önüne geçebilmek için gen veri tabanı belirlenmeli, gen bankaları kurulmalı ve genetik kaynaklarının korunması için in-situ ve ex-situ alanlar oluşturulmalıdır (Elmas, 2019). Bunlar dışında, ekonomik değeri yüksek olan adaçayı türlerinin ekiminin arttırılması, artan talebi karşılamak ve doğal popülasyonlar üzerindeki hasat baskısını hafifletmek için önemli bir stratejidir.

Sonuç olarak, adaçayının sürdürülebilir şekilde tarımının yapılması ve ticari potansiyelinin en iyi şekilde değerlendirilmesi için, tüketici ve sanayici taleplerini karşılayacak miktarda, standartlara uygun etken madde içeren, yüksek verim ve kalitede ürün veren, ülkemiz ekolojik koşullarına uygun olan çeşitlerle yetiştiriciliğinin yaygınlaştırılması gerekir. Pazarlama perspektifinden bakıldığında adaçayının ıslahı ve yetiştirilmesinin,

1. ürün kontrolünün ve sertifikasyonunun sağlanması ile botanik açıdan güvenilir ürünlerin elde edilmesi,

2. güvenilir sabit hammadde kaynağını sağlayabilmesi,

3. kontrollü hasat sonrası titiz bir şekilde işlenmesi,

4. ürün standartlarının düzenlemelere ve tüketici tercihlerine göre ayarlanması,

5. üretim miktarı ve fiyat konusunda yetiştiriciler ve toptancılar (veya ilaç şirketlerinin şirketleri) arasında iyi bir uyum sağlanması gibi bir dizi avantaj sunar (Laird ve Pierce, 2002; Rao ve ark., 2004). 
$\mathrm{Bu}$ derlemede önceki araştırmalar referans alınarak, adaçayının iklim ve toprak istekleri, üretim tekniği ve ekimi, bakım ve gübreleme uygulamaları, hasat ve kurutma işlemleri, verim değerleri, ekstraksiyonu, hastalık ve zararlıları, kalite ve muhafazası ile yetiştiricilikte Tarım ve Orman Bakanlığı tarafından verilen destekler hakkında bilgi verilmiştir. Bu çalışma, ticari öneme sahip doğal yetişen Salvia tomentosa Mill. ve Salvia fruticosa Mill. türleri ile yetiştiriciliği yapılan Salvia officinalis türleri ile ilgili çalışmaları kapsamaktadır. Bu derlemenin, adaçayı ile ilgili yapılacak çalışmalarda hem araştırmacılara ve hem de yetiştiricilere fikir vermesi amaçlanmıştır.

\section{Çıkar Çatışması Beyanı}

Yazar, çıkar çatışması olmadığını beyan eder.

\section{Araştırma ve Yayın Etiği Beyanı}

Yapılan çalışmada, araştırma ve yayın etiğine uyulmuştur.

\section{Kaynaklar}

Abacıoğlu, E., (2019). Adaçayı (Salvia officinalis L.) tohumlarında hormon uygulamalarının çimlenme ve fidecik karakterlerine etkisi. Yüksek Lisans Tezi, Kastamonu Üniversitesi, Fen Bilimleri Enstitüsü, Kastamonu.

Acıbuca, V., ve Budak, D. B., (2018). Dünya'da ve Türkiye'de tıbbi ve aromatik bitkilerin yeri ve önemi. Çukurova Tarım ve Gida Bilimleri Dergisi, 33 (1): 37-44.

Alkaya, D. B., Karaderi, S., Erdoğan, G., ve Cücü, A. K., (2015). İstanbul aktarlarında satılan bitkisel çaylarda ağır metal tayini. Marmara Pharmaceutical Journal, 19 (2): 136-140.

Altındal, D., ve Akgün, İ., (2015). Bitki genetik kaynakları ve tahıllardaki durumu. Adnan Menderes Üniversitesi Ziraat Fakültesi Dergisi, 12 (1): 147-153.

Arslan, N., Gürbüz, B., ve Yılmaz, G., (1995). Adaçayı (Salvia officinalis L.)'inda tohum tutma oranı ve İndol Butirik Asitin (IBA) gövde çeliklerinin köklenmesine etkileri üzerinde araştırmalar. Tr. J. of Agriculture and Forestry, TÜBİTAK, 19: 83-87.

Aşkun, T., Başer, K. H. C., Tümen, G., ve Kürkçüoğlu, M., (2010). Characterization of essential oils of some Salvia species and their antimycobacterial activities. Turkish Journal of Biology, 34: 89-95.

Ay, T. S., (2005). Antalya florasında yaygın olarak bulunan adaçayı (Salvia spp.), kekik (Thymus, Origanum spp.) türlerinin agronomik ve kalite değerlerinin belirlenmesi. Doktora Tezi, Akdeniz Üniversitesi, Fen Bilimleri Enstitüsü, Antalya.

Ayanoğlu, F., ve Özkan, C. F., (2000). Change in tissue mineral elemental concentration during root initiation and development of Salvia officinalis L. cuttings and IBA effects. Turkish Journal of Agriculture and Forestry, 24 (6): 677-682.

Aydın, D., Katar, N., Katar, D., ve Olgun, M., (2019). Farklı kurutma sıcaklıklarının Anadolu adaçayının (Salvia fruticosa Mill.= Salvia triloba L.) uçucu yağ oranı ve bileşenleri üzerine etkisinin belirlenmesi. Uluslararası Tarım ve Yaban Hayatı Bilimleri Dergisi, 5 (1):103-109.

Aziz, E.E., Sabry, R.M., and Ahmed, S.S., (2013). Plant growth and essential oil production of sage (Salvia officinalis L.) and curly-leafed parsley (Petroselinum crispum ssp. crispum L.) cultivated under salt stress conditions. World Applied Sciences Journal, 28 (6): 785-796. 
Elmas, S., Uluslararası Doğu Anadolu Fen Mühendislik ve Tasarım Dergisi / International Journal of Eastern Anatolia Science Engineering and Design (IJEASED)

(2021) 3(1):298-332

Bağc1, E., ve Koçak, A., (2008). Salvia palaestina Bentham ve Salvia tomentosa Miller türlerinin uçucu yağ kompozisyonu, kemotaksonomik bir yaklaşım. Fırat Üniversitesi Fen ve Mühendislik Bilimleri Dergisi, 20: (1) 35-41.

Bağdat, R. B., (2006). Tıbbi ve aromatik bitkilerin kullanım alanları, tıbbi adaçayı (Salvia Officinalis L.) ve ülkemizde kekik adıyla bilinen türlerin yetiştirme teknikleri. Tarla Bitkileri Merkez Araştırma Enstitüsü Dergisi, 15 (1-2): 19-28.

Baj, T., Ludwiczuk, A., Sieniawska, E., Skalicka-Woźniak, K., Widelski, J., Zieba, K., ve Głowniak, K., (2013). GC-MS analysis of essential oils from Salvia officinalis L.: comparison of extraction methods of the volatile components. Acta poloniae pharmaceutica, 70 (1): 35-40.

Başer, K. H. C., (2002). Aromatic biodiversity among the flowering plant taxa of Turkey. Pure and Applied Chemistry, 74 (4): 527-545.

Başyiğit, M., ve Baydar, H., (2017). Tıbbi adaçayı (Salvia officinalis L.)'nda farklı hasat zamanlarının uçucu yağ ve fenolik bileşikler ile antioksidan aktivite üzerine etkisi. Süleyman Demirel Üniversitesi Fen Bilimleri Enstitüsü Dergisi, 21 (1): 131-137.

Baydar, H., (2013). Tibbi ve aromatik bitkileri bilimi ve teknolojisi (Genişletilmiş 4. Baskı). Süleyman Demirel Üniversitesi Yayınları, Yayın No: 51, Isparta.

Bayraktar, Ö. V., Öztürk, G., ve Arslan, D., (2017). Türkiye'de bazı tıbbi ve aromatik bitkilerin üretimi ve pazarlamasındaki gelişmelerin değerlendirilmesi. Tarla Bitkileri Merkez Araştırma Enstitüsü Dergisi, 26 (2): 216-229.

Bayram, E., (2001). Batı Anadolu florasında yetişen Anadolu adaçayı (Salvia fruticosa Mill.)'nda uygun tiplerin seleksiyonu üzerinde araştırma. Turkish Journal of Agriculture and Forestry, 25: 351-357.

Bayram, E., Ceylan, A., Geren. H., (1999). Anadolu adaçayı (Salvia fruticosa Mill.) 1slahında geliştirilen klonların agronomik ve kalite özellikleri üzerinde araştırma (Cilt II, 212-217). Türkiye 3. Tarla Bitkileri Kongresi, Adana.

Bayram, E., Kırıc1, S., Tansi, S., Yıkmaz, G., Kızıl, O. A. S., ve Telci, İ., (2010). Tibbi ve aromatik bitkiler üretiminin arttirilmasi olanaklari. TMMOB Ziraat Mühendisleri Odasi, Ziraat Mühendisligi VII. Teknik Kongresi, 11-15.

Bayram, E., ve Sönmez, Ç., (2006). Adaçayı yetiştiriciliği. Ege Üniversitesi Tarımsal Uygulama ve Araştırma Merkezi Bülteni, (48), 8.

Bettaieb, I., Zakhama, N., Wannes, W. A., Kchouk, M., ve Marzouk, B., (2009). Water deficit effects on Salvia officinalis fatty acids and essential oils composition. Scientia horticulturae, 120 (2): 271-275.

Bourgaud, F., Gravot, A., Milesi, S., ve Gontier, E., (2001). Production of plant secondary metabolites: a historical perspective. Plant Science, 161 (5): 839-851.

Ceylan, A., (1996). Tıbbi bitkiler-II (Uçucu Yağ Bitkileri) EÜ ZF Yayınları No: 481. Bornova, İzmir, 225240.

Ceylan, A., Kaya, N., ve Çelik, N., (1990). Tıbbi adaçayının (Salvia officinalis L.) kültürü üzerinde araştırmalar. Ege Üniversitesi Ziraat Fakültesi Dergisi, 26 (1): 127-142.

Ceylan, A., Yurtsever, M., ve Ozonsoy, Y., (1979). Salvia officinalis L.'nin agronomik ve teknolojik özelliklerine azotlu gübrelemenin etkisi üzerinde araştırma. Ege Üniversitesi Ziraat Fakültesi Dergisi, 16 (3): 83-95.

Çakır, E., Bağdat, B. R., ve Çınar, O., (2016). Tıbbi adaçayı (Salvia officinalis L.) yetiştiriciliğinde sorun olan fungal hastalık etmenleri (76). III. Tibbi ve Aromatik Bitkiler Sempozyumu Bildirileri, Antalya.

Çamlıca, M., Yaldız, G., Özen, F., Başol, A., ve Aşkın, H., (2019). Effects of selenium applications on salt stress in sage and mountain tea. Turkish Journal of Agriculture-Food Science and Technology, 7 (sp2): 29-35.

Dinçer, C., (2007). Bazı adaçayı (Salvia spp.) ve dăg çayı (Sideritis spp.) türlerinin kimyasal ve duyusal özelliklerinin belirlenmesi. Yüksek Lisans Tezi, Akdeniz Üniversitesi, Fen Bilimleri Enstitüsü, Antalya. 
Dumanoğlu, Z., ve Mokhtarzadeh, S., (2020). Türkiye'de kültürü yapılan Salvia türlerine (Salvia hispanica L., Salvia tomentosa L. ve Salvia verticillata L.) ait tohumların bazı fiziksel özellikleri. Türk Tarım ve Doğa Bilimleri Dergisi, 7 (3): 596-602.

Duru, M. E., Güvenalp, Z., Harmandar, M., ve Hırata, T., (1994) Stachys Obliqua'nın toprak üstü kısımlarından elde edilen uçucu yağların kimyasal bileşiminin analizi.

Ekren, S., Sönmez, Ç., Sancaktaroğlu, S., ve Bayram, E., (2007). Farklı biçim yüksekliklerinin adaçayı (Salvia officinalis L.) genotiplerinde agronomik ve teknolojik özelliklere etkisinin belirlenmesi. Ege Üniversitesi Ziraat Fakültesi Dergisi, 44 (1): 55-70.

Elmas, S., (2019). Muğla yöresinde doğal yayılış gösteren Salvia fruticosa Mill. populasyonlarının morfolojik, kimyasal ve moleküler karakterizasyonunun belirlenmesi. Doktora Tezi, Muğla Sitk1 Koçman Üniversitesi, Fen Bilimleri Enstitüsü, Muğla.

Elmas, S., ve Elmas, O., (2021). Salvia fruticosa'nın (Anadolu adaçayı) terapötik etkileri. International Journal of Life Sciences and Biotechnology, 4 (1-2): 114-137.

Faydaoğlu, E., ve Sürücüoğlu, M. S., (2011). Geçmişten günümüze tıbbi ve aromatik bitkilerin kullanılması ve ekonomik önemi. Kastamonu Üniversitesi Orman Fakültesi Dergisi, 11 (1): 52-67.

Feizi, H., Amirmoradi, S., Abdollahi, F., ve Pour, S.J., (2013). Comparative effects of nanosized and bulk titanium dioxide concentrations on medicinal plant Salvia officinalis L. Annual Review \& Research in Biology. 3(4): 814-824.

Flórez, M., Martínez, E., ve Carbonell M.V., (2012). Effect of magnetic field treatment on germination of medicinal plants Salvia officinalis L. and Calendula officinalis L. Polish Journal of Environmental Studies, 21: 57-63.

Gül, S., Çevik, G., Gül, M., ve Özel, N., (2002). Ege Bölgesinde İzmir kekiği (Origanum onites) ve adaçayının (Salvia triloba) yağ analizlerinden yararlanarak yörelere göre kesim zamanının belirlenmesi. Ege Ormancılık Araştırma Müdürlüğü, Teknik Bülten Serisi (21).

Güner, A., Aslan, S., Ekim, T., Vural, M., ve Babaç, M., (2012). Türkiye bitkileri listesi. Damarlı bitkiler, Nezahat Gökyiğit Botanik Bahçesi ve Flora Araştırmaları Derneği Yayını (s 262).

Hartmann, H.T., Kester, D.E., Davies, F., ve Geneve, Y.R., (1997). Plant Propagation: Principles and practices. (6th ed) (pp. 770), Prentice-Hall, Upper Saddle River: New Jersey.

Hatipoğlu, S. D., (2017). Bazı Salvia türlerinin sekonder metabolitlerinin analizi, genomik karakterizasyonu ve biyolojik aktivitelerinin incelenmesi. Doktora Tezi, İstanbul Teknik Üniversitesi, Fen Bilimleri Enstitüsü, İstanbul.

Hazairin, Z. A., (2018). Adaçayı (Salvia officinalis L.)'nda zararlı böcekler ve doğal düşmanları ile etkileşimleri. Doktora Tezi, Ege Üniversitesi, Fen Bilimleri Enstitüsü, İzmir.

Haznedaroğlu, M. Z., Karabay, N.Ü., Zeybek. U., (2001). Antibacterial activity of Salvia tomentosa Mill. essential oil. Journal of Fitoterapia, 72: 829-831.

Hendawy, S., ve Khalid, K. A., (2005). Response of sage (Salvia officinalis L.) plants to zinc application under different salinity levels. J. Appl. Sci. Res, 1 (2): 147-155.

İpek, A. ve Gürbüz, B., (2010) Türkiye florasında bulunan Salvia türleri ve tehlike durumları, Tarla Bitkileri Merkez Araştırma Enstitüsü Dergisi, 19 (1): 30-35.

İpek, A., (2007). Tıbbi adaçayı (Salvia officinalis) hatlarında azotlu gübrelemenin herba verimi ve bazı özellikler üzerine etkileri. Doktora Tezi, Ankara Üniversitesi, Fen Bilimleri Enstitüsü, Ankara.

İzci, B., (2020). T1bbi adaçayı tohumlarına uygulanan farklı hormon ve dozlarının morfolojik özellikler üzerine etkisi. Erciyes Tarım Ve Hayvan Bilimleri Dergisi, 3 (1): 1-8.

Jouyban, Z., (2012). The effects of salt stress on plant growth. Technical Journal of Engineering and Applied Sciences, 2 (1): 7-10.

Kaplan, M., Kocabaş, I., Sönmez, I., ve Kalkan, H., (2007). The effects of different organic manure applications on the dry weight and the essential oil quantity of sage (Salvia fruticosa Mill.) (pp. 147152). In I International Medicinal and Aromatic Plants Conference on Culinary Herbs, Antalya. 
Elmas, S., Uluslararası Doğu Anadolu Fen Mühendislik ve Tasarım Dergisi / International Journal of Eastern Anatolia Science Engineering and Design (IJEASED)

(2021) 3(1):298-332

Kara, N., Baydar, H., ve Erbaş, S., (2011). Farklı çelik alma dönemleri ve IBA dozlarının bazı tıbbi bitkilerin köklenmesi üzerine etkileri. Batı Akdeniz Tarımsal Araștırma Enstitüsü Derim Dergisi, 28 (2):71-81.

Karaaslan, D., (1994). Salvia populasyonlarinda farkll azot uygulamalarinda drog verimi ve kemotaksonomik araştırmalar. Yüksek Lisans Tezi, Çukurova Üniversitesi Fen Bilimleri Enstitüsü, Adana.

Karaca, M., Ince, A. G., Ay, S. T., Turgut, K., ve Onus, A. N., (2008). PCR- RFLP and DAMD- PCR genotyping for Salvia species. Journal of the Science of Food and Agriculture, 88 (14): 2508-2516.

Karakuş, M., Baydar, H., ve Erbaş, S., (2017). Tıbbi adaçayı (Salvia officinalis L.) populasyonundan geliştirilen klonların verim ve uçucu yağ özellikleri. Tarla Bitkileri Merkez Araştırma Enstitüsü Dergisi, 26: 99-104.

Karayel, H. B., (2019). Bazı adaçayı (Salvia spp.) türlerinin verim ve kalite özellikleri bakımından genotip $x$ çevre etkileşimlerinin araştırılması. Doktora Tezi, Çanakkale Onsekiz Mart Üniversitesi, Fen Bilimleri Enstitüsü, Çanakkale.

Karayel, H. B., ve Akçura, M., (2016). Farklı lokasyonlarda yetiştirilen Anadolu adaçayı (Salvia fruticosa Mill.)'in uçucu yağ bileşenlerindeki değişimlerin incelenmesi. Gaziosmanpaşa Bilimsel Araştırma Dergisi, (13): 13-23.

Karık, Ü., (2015). Some morphological, yield and quality characteristics of Anatolian sage (Salvia fruticosa Mill.) populations in Aegean and West Mediterranean Region. Journal of Tekirdag Agricultural Faculty, 12 (2): 32-42.

Karık, Ü., Sağlam, A. C., ve Kürkçüoğlu, M., (2013). Güney Marmara florasındaki adaçayı (Salvia tomentosa Mill.) populasyonlarının bazı morfolojik ve kalite özellikleri. Anadolu Ege Tarımsal Araştırma Enstitüsü Dergisi, 23 (2): 9-20.

Karı, Ü., ve Sağlam, A., (2017). Determination of the yield and quality characteristics of anatolian sage (Salvia fruticosa Mill.) populations in Tekirdağ ecological conditions. Journal of Central Research Institute for Field Crops, 26 (2): 203-215.

Karousou, R., Hanlidou, E., ve Kokkini, S., (2000). II. Botany. The sage plants of Greece: distribution and infraspecific variation. Sage. The Genus Salvia, 27-53.

Katar, D., Katar, N., Can, M., (2019). Farklı azot dozlarının Anadolu adaçayı (Salvia triloba Mill.)'nda verim ve verim komponentleri üzerine etkisinin belirlenmesi (33-45). II. Hasat Uluslararası Tarım Ve Orman Kongresi, İzmir: Ege Üniversitesi.

Katar, N., Katar, D., Aydın, D., ve Olgun, M., (2018). Tıbbi adaçayı (Salvia officinalis L.)'nda uçucu yağ oranı ve kompozisyonu üzerine ontogenetik varyabilitenin etkisi. Uluslararası Tarım ve Yaban Hayatı Bilimleri Dergisi, 4 (2): 231-236.

Kılıç, S., ve Bölükbaşı, M., (2020). Phytochemical accumulation with photomorphogenesis and physiology of Salvia officinalis L. Acta Scientiarum Polonorum-Hortorum Cultus, 19 (5): 101-113.

Kocabaş, I., Kaplan, M., Kürkçüoğlu, M., ve Başer, K. H. C., (2010). Effects of different organic manure applications on the essential oil components of Turkish sage (Salvia fruticosa Mill.). Asian Journal of Chemistry, 22 (2): 1599-1605.

Kocabaş, I., Sönmez, İ., Kalkan, H., ve Kaplan, M., (2007). Farklı organik gübrelerin adaçayı (Salvia fruticosa Mill.)'nın uçucu yağ oranı ve bitki besin maddeleri içeriğine etkileri. Akdeniz Üniversitesi Ziraat Fakültesi Dergisi, 20 (1): 105-110.

Koç, H., 2000. Tıbbi adaçayı (Salvia officinalis L.)'nda azotlu gübrelemenin verim ve kalite üzerine etkisi. Gaziosmanpaşa Üniversitesi Ziraat Fakültesi Dergisi, 17(1): 89.

Koç, P.O., (2006). Azot ve kükürdün adaçayı (Salvia Officinalis) bitkisinin herba verimi ve bazı kalite parametreleri üzerine etkisi. Yüksek Lisans Tezi, Ankara Üniversitesi, Fen Bilimleri Enstitüsü, Ankara.

Koşar, M., Tunalier, Z., Özek, T., Kürkcüoglu, M., ve Baser, K. H. C., (2005). A simple method to obtain essential oils from Salvia triloba L. and Laurus nobilis L. by using microwave-assisted hydrodistillation. Zeitschrift für Naturforschung C, 60 (5-6): 501-504. 
Kulak, M., Gul, F., ve Sekeroglu, N., (2020). Changes in growth parameter and essential oil composition of sage (Salvia officinalis L.) leaves in response to various salt stresses. Industrial Crops and Products, 145: 112078.

Laird, S.A., ve Pierce, A.R., (2002). Promoting sustainable and ethical botanicals. Strategies to improve commercial raw material sourcing. Rainforest Alliance, New York.

Lakušić, B., Ristić, M., Slavkovska, V., Stojanović, D., \& Lakušić, D., (2013). Variations in essential oil yields and compositions of Salvia officinalis (Lamiaceae) at different developmental stages. Botanica Serbica, 37 (2): 127-139.

Lu, Y., ve Foo, L. Y., (2002). Polyphenolics of Salvia - a review. Phytochemistry, 59 (2): 117-140.

Mammadov, R., (2014). Tohumlu bitkilerde sekonder metobolitler. Nobel Akademik Yayınc1lık.

Mapes, C., ve Xu, Y., (2014). Photosynthesis, vegetative habit and culinary properties of sage (Salvia officinalis) in response to low-light conditions. Canadian Journal of Plant Science, 94 (5): 881-889.

Martin, E., Altınordu, F., Celep, F., Kahraman, A., ve Doğan, M., (2015). Karyomorphological studies in seven taxa of the genus Salvia (Lamiaceae) in Turkey. Caryologia, 68 (1): 13-18.

Meral, B., (2020). E-ticarette corona virüs (Covid-19) etkisi. Tech Insade.

Munné-Bosch, S., Mueller, M., Schwarz, K., ve Alegre, L., (2001). Diterpenes and antioxidative protection in drought-stressed Salvia officinalis plants. Journal of plant physiology, 158 (11): 1431-1437.

Nakipoğlu, M., (1993) Bazı Adaçayı (Salvia L.) türleri ve bu türlerin ekonomik önemi, Dokuz Eylül Üniversitesi Ĕ̈itim Bilimleri Dergisi 6: 45-58.

Nowak, M., Kleinwaechter, M., Manderscheid, R., Weigel, H.-J., ve Selmar, D., (2010). Drought stress increases the accumulation of monoterpenes in sage (Salvia officinalis), an effect that is compensated by elevated carbon dioxide concentration. Journal of Applied Botany and Food Quality, 83 (2): 133136.

Okigbo, R., Anuagasi, C., ve Amadi, J., (2009). Advances in selected medicinal and aromatic plants indigenous to Africa. Journal of Medicinal Plants Research, 3 (2): 086-095.

Önal, H., (2015). Muğla Fethiye Babadağı doğal adaçayı (Salvia sp.) taksonlarında farklı toplama zamanlarının yaprak uçucu bileşenleri üzerine etkisi. Yüksek Lisans Tezi, Süleyman Demirel Üniversitesi, Isparta.

Öz, M., (2002). Bursa Mustafakemalpaşa ekolojik koşullarında değişik bitki sıklıklarının bazı kışlık kolza çeşitlerinin performansı üzerine etkileri. Uludağ Üniversitesi Ziraat Fakültesi Dergisi, 16 (2): 11-24.

Özbek, H., (2005). Cinsel ve jinekolojik sorunların tedavisinde bitkilerin kullanımı. Van Tıp Dergisi, 12 (2): $170-174$.

Özcan, İ. İ., Arabacı, O., ve Öğretmen, N. G., (2014). Bazı adaçayı türlerinde farklı tohum çimlendirme uygulamalarının belirlenmesi. Türk Tarım-Gıda Bilim ve Teknoloji Dergisi, 2 (5): 203-207.

Özek, R., (2019). Siirt ekolojik koşullarında farklı sıra üzeri mesafelerinin adaçayında (Salvia officinalis L.) bazı kalite kriterlerine ve uçucu yă̆ kompozisyonuna etkisi. Yüksek Lisans Tezi, Siirt Üniversitesi, Fen Bilimleri Enstitüsü, Siirt.

Özkeskin, E., (2019). Tokat-Kazova koşullarında farklı gelişsim dönemlerinin adaçayı (Salvia officinalis L.) bitkisinde verim ve kalite özeliklerine etkisi. Yüksek Lisans Tezi, Tokat Gaziosmanpaşa Üniversitesi, Fen Bilimleri Enstitüsü, Tokat.

Öztürk, N. Z., (2015). Bitkilerin kuraklık stresine tepkilerinde bilinenler ve yeni yaklaşımlar. Turkish Journal Of Agriculture-Food Science And Technology, 3 (5): 307-315.

Özyazıc1, M.A., Dengiz, O., Aydoğan, M., Bayrakl1, B., Kesim, E., Urla, Ö., Yı1dız, H., Ünal, E., (2015). Orta ve Doğu Karadeniz Bölgesi tarım topraklarının bazı makro ve mikro bitki besin maddesi konsantrasyonları ve ters mesafe ağırlık yöntemi (IDW) ile haritalanması. Artvin Çoruh Üniversitesi Orman Fakültesi Dergisi, 16 (2): 187-202.

Polat, Z., ve Tınmaz, A. B., (2014). Anadolu adaçayında bazı biyolojik ajan uygulamalarının verim, kalite ve toprak kaynaklı hastalıklara karşı etkisi (701-703). 2. Tıbbi ve Aromatik Bitkiler Sempozyumu, Yalova: Atatürk Bahçe Kültürleri Merkez Araştırma Enstitüsü. 
Elmas, S., Uluslararası Doğu Anadolu Fen Mühendislik ve Tasarım Dergisi / International Journal of Eastern Anatolia Science Engineering and Design (IJEASED)

(2021) 3(1):298-332

Polatc1, H., ve Tarhan, S., (2009). Farklı kurutma yöntemlerinin reyhan (Ocimum basilicum) bitkisinin kuruma süresine ve kalitesine etkisi. Gaziosmanpaşa Üniversitesi Ziraat Fakültesi Dergisi, 26 (1): 6170.

Rao, M. R., Palada, M. C., ve Becker, B. N., (2004). Medicinal and aromatic plants in agroforestry systems. In New Vistas in Agroforestry, 107-122.

Rezai, S., Etemadi, N., Nikbakht, A., Yousefi, M., Majidi, M.M., (2018). Effect of light 1ntensity on leaf morphology, photosynthetic capacity, and chlorophyll content in sage (Salvia officinalis L.). Horticultural Science and Technology, 36 (1): 46-57.

Schulz, H., Özkan, G., Baranska, M., Kruger, H., ve Özcan, M., (2005). Characterisation of essential oil plants from Turkey by IR and Raman spectroscopy. Vibrational Spectroscopy, 39: 249-256.

Skoula, M., Abbes, J. E., ve Johnson, C. B., (2000). Genetic variation of volatiles and rosmarinic acid in populations of Salvia fruticosa Mill growing in Crete. Biochemical Systematics and Ecology, 28(6): 551-561.

Sönmez, Ç., (2015). Bitki-su ilişkilerinin tıbbi adaçayı (Salvia officinalis L.)'nın verim, uçucu yă̆ üretimi ve kalitesi üzerine etkileri: Biyometrik ve fizyolojik incelemeler. Doktora Tezi, Ege Üniversitesi, Fen Bilimleri Enstitüsü, İzmir.

Sönmez, Ç., Gökçöl, A., Soysal, A. Ö. Ş., Bayram, E., ve Çelen, A. E., (2019). Research on germination and emergence performance enhancing treatments on sage (Salvia spp.) species. Turkish Journal of Agriculture-Food Science and Technology, 7(3): 504-510.

Sönmez, Ç., ve Bayram, E., (2017). The influence of different water and nitrogen applications on some yield parameters and antioxidant activity in sage (Salvia officinalis L.). Turkish Journal Of Field Crops, 22 (1): 96-103.

Şarer, E., (1980). Anadolu'da yetişen Salvia tomentosa Mill. ve Salvia grandiflora Etling. uçucu yağlarının özelikleri ve içerikleri bakımından karşılaştırılması. Journal of Faculty of Pharmacology, 10: 112-123.

Şenkal, B. C., Arif, İ., Gürbüz, B., Türker, A., ve Bingöl, M. Ü., (2012). Bolu ekolojik koşullarında yetiştirilen Salvia officinalis L. ve Salvia tomentosa L. türlerinin bazı önemli tarımsal özelliklerinin belirlenmesi. International Journal of Agricultural and Natural Sciences, 5(2): 38-42.

Taarit, M. B., Msaada, K., Hosni, K., Hammami, M., Kchouk, M. E., ve Marzouk, B., (2009). Plant growth, essential oil yield and composition of sage (Salvia officinalis L.) fruits cultivated under salt stress conditions. Industrial Crops and Products, 30 (3): 333-337.

Taarit, M. B., Msaada, K., Hosni, K., ve Marzouk, B., (2010). Changes in fatty acid and essential oil composition of sage (Salvia officinalis L.) leaves under NaCl stress. Food Chemistry, 119 (3): 951956.

Tepe, B., Daferera, D., Sökmen, A., Sökmen, M., ve Polissiou, M., (2006). Antimicrobial and antioxidant activities of the essential oil and various extracts of Salvia tomentosa Miller (Lamiaceae). Food Chemistry, 90: 333-340.

Tıbbi Adaçayı Yaygınlaştırma Raporu, (2018). Orta Anadolu Kalkınma Ajansı.

Topçu, G., (2006). Bioactive triterpenoids from Salvia species. Journal of natural products, 69 (3): 482-487.

Torun, H., (2019). Cobalt+salt-stressed Salvia officinalis: ROS scavenging capacity and antioxidant potency. International Journal of Secondary Metabolite, 6 (1): 49-61.

Tounekti, T., Abreu, M. E., Khemira, H., ve Munné-Bosch, S., (2012). Canopy position determines the photoprotective demand and antioxidant protection of leaves in salt-stressed Salvia officinalis L. plants. Environmental and Experimental Botany, 78: 146-156.

Tounekti, T., Hernández, I., Müller, M., Khemira, H., ve Munné-Bosch, S., (2011). Kinetin applications alleviate salt stress and improve the antioxidant composition of leaf extracts in Salvia officinalis. Plant Physiology and Biochemistry, 49 (10): 1165-1176.

Tuğlu, Ü., ve Baydar, H., (2019). Tıbbi adaçayı (Salvia officinalis L.)'nda klon seleksiyonu ile geliştirilmiş b-klonlarının tarımsal ve teknolojik özellikleri. Süleyman Demirel Üniversitesi Fen Bilimleri Enstitüsü Dergisi, 23 (2): 452-456. 
Tuna, U., (2019). Türkmen Dağının Kütahya ili Türkmen Şefliği bölgesi civarındaki adaçayı (Salvia tomentosa L.) bitkisinin yayılış durumu ve biyokütlesinin belirlenmesi. Yüksek Lisans Tezi, Dumlupınar Üniversitesi, Fen Bilimleri Enstitüsü, Kütahya.

Turan, Ş., (2014). Ülkemizde yaygın olarak kullanılan bazı tıbbi bitkilerin yapraklarında ağır metal ve mineral besin element içeriklerinin tayini. Yüksek Lisans Tezi, Marmara Üniversitesi, Fen Bilimleri Enstitüsü, İstanbul.

Turhan, P., (2020). Kuru ve sulu koşullarda yetiştirilen Anadolu adaçayında (Salvia fruticosa Mill.) farklı azot dozu ve hasat zamanlarının verim ve kalite üzerine etkileri. Doktora Tezi, Tekirdağ Namık Kemal Üniversitesi, Fen Bilimleri Enstitüsü, Tekirdağ.

TÜiK, (2021). Dış Ticaret İstatistikleri. https://biruni.tuik.gov.tr/disticaretapp/disticaret.zul?param1=25veparam2=0vesitcrev=0veisicrev=0ves ayac=5802 Erişim 09 Şubat 2021.

Ulukanlı, Z., Karabörklü, S., Cenet, M., Sağdıç, O., Öztürk, İ., Balcılar, M., (2013). Essential oil composition, insecticidal and antibacterial activities of Salvia tomentosa Miller. Medicinal Chemistry Research, 22: (2) 832-840.

Vural, A., Güran, H. Ş., Durmuşoğlu, H., ve Uğur, U., (2020). Tıbbi amaçla kullanılabilen bitki çaylarında hijyenik kalitenin ve bazı patojenlerin araştırılması. Dicle Üniversitesi Veteriner Fakültesi Dergisi, 13 (1): 76-82.

Yağcıŏlu, P., (2015). Farklı ekstraksiyon metotları ile adaçayı (Salvia officinalis L.) bitkisinden antioksidan ekstraksiyonunun optimizasyonu. Yüksek Lisans Tezi, İstanbul Teknik Üniversitesi, Fen Bilimleri Enstitüsü, İstanbul.

Yılmaz, G., ve Güvenç, A., (2007). Ankara'da aktarlarda "adaçayı" adı altında satılan drogların morfolojik ve anatomik olarak incelenmesi. Ankara Üniversitesi Eczacıllk Fakültesi Dergisi, 36 (2): 87-104.

Yılmaz, O., (2019). Anadolu adaçayı (Salvia fruticosa Mill.)'nda azotlu gübrenin ve hasat zamanlarının agronomik ve teknolojik özellikler üzerine etkileri. Yüksek Lisans Tezi, Adnan Menderes Üniversitesi, Fen Bilimleri Enstitüsü, Aydın.

Yurdcu, S., (2019). Bazı tıbbi adaçayı (Salvia officinalis L.) hatlarının kuraklık stresine dayanıklılı̆̆ının belirlenmesi. Yüksek Lisans Tezi, Çankırı Karatekin Üniversitesi, Fen Bilimleri Enstitüsü, Çankırı.

Zarkani, A., Turanli, F., Sönmez, Ç., Bayram, E., ve Özdemir, İ., (2017). Incidence and economic impact of the mint aphid, Eucarazzia elegans (Ferrari)(Hemiptera: Aphididae) on common sage. Türkiye Entomoloji Dergisi, 41(4): 383-392.

Zervoudakis, G., Salahas, G., Kaspiris, G., ve Konstantopoulou, E., (2012). Influence of light intensity on growth and physiological characteristics of common sage (Salvia officinalis L.). Brazilian Archives of Biology and Technology, 55 (1): 89-95.

Zimowska, B., (2008). Fungi threatening the cultivation of sage (Salvia officinalis L.) in south-eastern Poland. Herba Polonica, 54 (1): 15-24.

Zutic, I., Putievsky, E., ve Dudai, N., (2004). Influence of harvest dynamics and cut height on yield components of sage (Salvia officinalis L.). Journal of Herbs, Spices \& Medicinal Plants, 10 (4): 4961. 